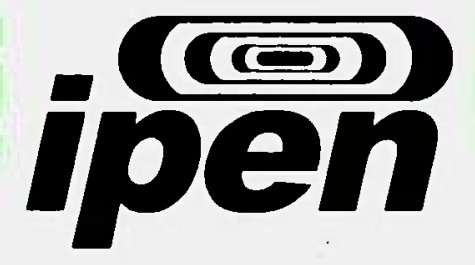

AUTARQUIA ASSOCIADA À UNIVERSIDADE DE SÃO PAULO

PREPARAÇÃo DE ELETROCATALISADORES PtRUNI/C

PELO MÉTODO DA REDUÇÃO POR ÁLCOOL PARA APLICAÇÃO COMO ÂNODO NA OXIDAÇÃO DIRETA DE METANOL EM CÉLULAS A COMBUSTÍVEL DE ELETRÓLITO POLÍMERICO SÓLIDO

VILMARIA APARECIDA RIBEIRO

Dissertação apresentada como parte dos requisitos para obtenção do Grau de Mestre em Ciências na Área de Tecnologia Nuclear - Materiais.

Orientador:

Dr. Estevam Vitorio Spinacé

São Paulo

2008 


\section{ipen}

INSTITUTO DE PESQUISAS ENERGÉTICAS E NUCLEARES AUTARQUIA ASSOCIADA À UNIVERSIDADE DE SĀO PAULO

\section{PREPARAÇÃO DE ELETROCATALISADORES PtRUNi/C PELO MÉTODO DA REDUÇÃO POR ÁLCOOL PARA} APLICAÇÃO COMO ÂNODO NA OXIDAÇÃO DIRETA DE METANOL EM CÉLULAS A COMBUSTIVEL DE ELETRÓLITO POLÍMERICO SÓLIDO

VILMARIA APARECIDA RIBEIRO

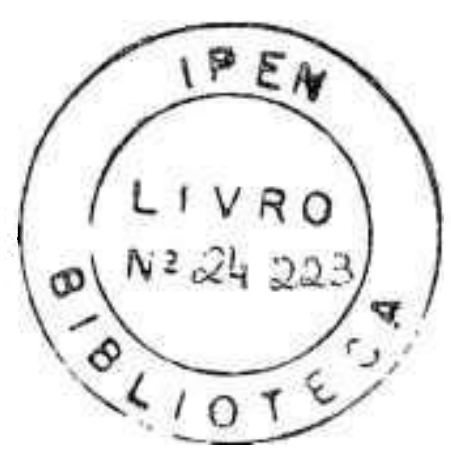

Dissertação apresentada como parte dos requisitos para obtenção do Grau de Mestre em Ciências na Área de Tecnologia Nuclear - Materiais.

Orientador:

Dr. Estevam Vitorio Spinacé

São Paulo

2008 
"Na busca desesperada de ter, o homem esquece de ser."

(Gustavo de Assis) 


\section{AGRADECIMENTOS}

Dedico sinceros agradecimentos ao Dr. Estevam Vitorio Spinacé pela orientação, colaboração e amizade dispensados no decorrer deste trabalho.

Ao Dr. Almir Oliveira Neto pela introdução aos conceitos eletroquímicos.

À Dra. Elisabete Inácio Santiago pelas sugestōes e dicas apresentadas ao longo deste trabalho.

Ao Dr. Marcelo Linardi pelo apoio.

À Dra. Marta Lucia Mora Bejarano por me incentivar e acreditar no meu potencial.

Ao Celso, Nildemar, Glauson e Olandir do CCTM pelas análises realizadas.

Aos amigos e colegas do laboratório de células a combustivel que trouxeram conhecimentos de suas respectivas áreas que muito contribuiram para a formação de um amkiente cultural diversificado e rico.

Aos amigos e irmãos que conquistei e que tiveram grande importância não só para realização deste trabalho, mas para vida; Nelson, Thais, Roberto, Maria e Mayara.

E a Deus por estar sempre ao meu lado. 


\title{
PREPARAÇÃO DE ELETROCATALISADORES PtRUNi/C PELO MÉTODO DA REDUÇÃO POR ÁLCOOL PARA APLICAÇÃO COMO ÂNODO NA OXIDAÇÃO DIRETA DE METANOL EM CÉLULAS A COMBUSTIVEL DE ELETROLITO POLÍMERICO SÓLIDO
}

\author{
Vilmaria Aparecida Ribeiro
}

\section{RESUMO}

Foi estudada a preparação de eletrocatalisadores PtRuNi/C (nanopartículas PtRuN: suportadas em carbono) pelo método da redução por álcool utilizando $\mathrm{H}_{2} \mathrm{PtCl}_{6} .6 \mathrm{H}_{2} \mathrm{O}, \mathrm{RuCl}_{3} .1,5 \mathrm{H}_{2} \mathrm{O}$ e NiCl $2.6 \mathrm{H}_{2} \mathrm{O}$ como fonte de metais, etileno glicol como solvente e agente redutor e Carbon Vulcan $X C 72 R$ como suporte. Os eletrocatalisadores obtidos foram caracterizados por análise de raios $X$ pór energia dispersiva (EDX), difração de raios $X(X R D)$, microscopia eletrônica de transmissão (TEM) e voltametria cíclica (CV). A eletro-oxidação do metanol foi estudada por voltametria ciclica e cronoamperometria visando aplicaçāo em células a combustivel a metanol direto (DMFC).

Inicialmente, os eletrocatalisadores PtRuNi/C (20\% em massa de metais) foram preparados com uma razão atômica Pt:Ru:Ni de 50:40:10 em meio ácido e em meio alcalino (razão molar $\mathrm{OH}^{-}$/metais $=8$ ) sendo que, neste caso, uma solução de $\mathrm{KOH} 1 \mathrm{~mol} \mathrm{~L}^{-1}$ foi adicionada ao meió reacional na proporção desejada. Para o material preparado em meio ácido foi observado apenas a redução dos ions Pt(IV) e Ru(III), enquanto que os ions Ni(il) permaneceram em solução. A redução dos ions $\mathrm{Ni}(\mathrm{II})$ e sua incorporação nas nanoparticulas metálicas ocorreu somente em meio alcalino. Neste caso observou-se uma estrutura cúbica de face centrada característica de Pt e suas ligas e também um menor tamanho de cristalito. Por outro lado, a quantidade de metais depositada no suporte de carbono foi de apenas $10 \%$. Foi estudada também a variação da razão atômica Pt:Ru:Ni (70:20:10, 60:30:10, 50:40:10, 50:25:25, 50:10:40 e 40:30:30) 
utilizando uma razão molar $\mathrm{OH}^{-} /$metais $=8$. Neste caso, os materiais obtidos apresentaram razōes atômicas Pt:Ru:Ni semelhantes as razões nominais e um aumento da quantidade de metais (\% massa) depositada no suporte de carbono foi observado com $\circ$ aumento da quantidade de $\mathrm{Ni}$ presente nos eletrocatalisadores. No entanto, a deposição da quantidade total de metais no suporte de carbono não foi observada em nenhum caso. Nestas condições, o eletrocatalisador PtRuNi/C com razão atômica 50:40:10 apresentou-se o mais ativo na eletro-oxidação do metanol. Dessa forma, foi realizado um estudo do efeito da razão molar $\mathrm{OH}^{-} /$metais para o eletrocatalisador PtRuNi/C (50:40:10) visando a redução total dos ions metálicos, bem como, a deposição total das nanopartículas formadas no suporte de carbono. Para isso, a razão atômica $\mathrm{OH}^{-}$ Imetais foi variada entre 4 e 12. Observou-se que a redução dos ionc $\mathrm{Pt}$ (IV) e $\mathrm{Ru}(I I I)$ ocorreu em toda a faixa estudada, no entanto, a redução dos ions $\mathrm{Ni}(\mathrm{II})$ só ocorreu a partir de uma razão molar $\mathrm{OH}^{-} /$metais igual a 6 . Para valores $\mathrm{OH}^{-}$ /metais entre 5 e 8 os tamanhos de cristalito apresentaram-se menores que $2 \mathrm{~nm}$, enquanto que, para valores menores que 5 e maiores que 10 ocorreu um aumento nos tamanhos. Por outro lado, a deposição total de metais sobre o suporte só foi observada para valores $\mathrm{OH}^{-} /$metais menores que 6 onde a redução dos ions $\mathrm{Ni}(\mathrm{II})$ não ocorreu. 


\title{
PREPARATION OF PIRUNI/C ELETROCATALYSTS PREPARED BY AN ALCOHOL REDUCTION PROCESS FOR METHANOL ELECTRO-OXIDATION IN DIRECT METHANOL FUEL CELL
}

\author{
Vilmaria Aparecida Ribeiro
}

\begin{abstract}
PtRuNi/C electrocatalysts (carbon-supported PtRuNi nanoparticles) were prepared by an alcohol-reduction process using $\mathrm{H}_{2} \mathrm{PtCl}_{6} .6 \mathrm{H}_{2} \mathrm{O}, \mathrm{RuCl}_{3} .1,5 \mathrm{H}_{2} \mathrm{O}$ and $\mathrm{NiCl}_{2} .6 \mathrm{H}_{2}$. as metal sources, ethylene glycol as solvent and reducing agent. and Vulcan XC $72 R$ as carbon support. The electrocatalysts were characterized by energy dispersive $X$-ray analysis (EDX), $X$-ray diffraction (XRD), transmission electron microscopy (TEM), thermogravimetric analysis (TGA) and cyclic voltammetry (CV). The electro-oxidation of methanol was studied by cyclic voltammetry and chronoamperometry aiming direct methanol fuel cell (DMFC) applications.

Initially, PtRuNi/C electrocatalysts (20 wt\%.) with Pt:Ru:Ni atomic ratio of 50:40:10 were prepared in acid and alkaline medium $\left(\mathrm{OH}^{-} /\right.$metals molar ratio $\left.=8\right)$ In alkaline medium, a solution of $\mathrm{KOH} 1 \mathrm{~mol} \mathrm{~L}^{-1}$ was added to the reaction medium. For the material prepared in acid medium only the reduction of $\mathrm{Pt}(\mathrm{IV})$ and $\mathrm{Ru}$ (III) occurs, while the $\mathrm{Ni}(\mathrm{II})$ ions remains in solution. The reduction of $\mathrm{Ni}(\mathrm{II})$ ions and its incorporation into the nanoparticles were observed for the materials prepared in alkaline medium. In this case, it was observed a face centered cubic structure (fcc) characteristic of $\mathrm{Pt}$ and $\mathrm{Pt}$ alloys and a smaller crystallite size. On the other hand, the total amount of metals deposited on the carbon support was only $10 \mathrm{wt} \%$. The Pt:Ru:Ni atomic ratio was varied $(70: 20: 10 ; 60: 30: 10 ; 50: 40: 10 ; 50: 25: 25 ; 50: 10: 40$ and 40:30:30) using an $\mathrm{OH}^{-} /$metals molar ratio $=8$. The obtained $\mathrm{Pt}: \mathrm{Ru}: \mathrm{Ni}$ atomic ratio were similar to the nominal ones and an increase of metals content ( $w t \%$ ) deposited on the carbon support was observed with the increase of Ni content on
\end{abstract}


the samples. However, the deposition of the total metals content on the carbon support was not observed in any case. In these conditions, the PtRuNi/C electrocatalyst with Pt:Ru: $\mathrm{Ni}$ atomic ratio of 50:40:10 was the most active for methanol electro-oxidation. In this manner, it was studied the effect of $\mathrm{OH}^{-} /$metals molar ratio for PtRuNi/C (50:40:10) electrocatalysts in order to reduce all metal ions, as well its total deposition on the carbon support. Thus, the $\mathrm{OH} /$ metals molar ratio was varied between 4 and 12. It was observed that the reduction of $\mathrm{Pt}(\mathrm{IV})$ and $\mathrm{Ru}(I I I)$ ions occurred in all range studied, however, the reduction of $\mathrm{Ni}(\mathrm{II})$ ions occurred only for $\mathrm{OH}^{-} /$metals atomic ratios greater than 6 . For $\mathrm{OH}^{-} /$metals values between 5 and 8 the crystallite sizes were smaller than $2 \mathrm{~nm}$, while for $\mathrm{OH}^{-1}$ metals smaller than 5 and greater than 8 an increase of the crystallite size occurs. On the other hand, the total metals (wt\%) dennsition on the carbon support was observed only for $\mathrm{OH}^{-} /$metals atomic ratios smaller than 6 , however, the $\mathrm{Ni}(\mathrm{II})$ ions reduction not occurred. 


\section{SUMÁRIO}

1 INTRODUÇÃO

1.1. Células a combustivel 1

1.2. Células a combustível de eletrólito polimérico sólido (PEMFC) 3

1.3. Célula a combustivel utilizando metanol diretamente como combustivel (Direct Methanol Fuel Cell - DMFC) 5

1.4. Mecanismo da Oxidação do Metanol sobre Platina e Platina Rutênio 6

1.5. Método da redução por álcool 8

1.5.1. Método da redução por álcool na preparação de eletrocatalisadores Pt/C e PtRu/C

1.5.2 Método de redução por álcool desenvolvido n: IPEN/CNENSP

1.6. Preparação de eletrocatalisadores PtRuNi/C para a eletro-oxidação de metanol.

2. OBJETIVOS

3. PROCEDIMENTOS EXPERIMENTAIS

3.1. Preparação e Caracterização dos Eletrocatalisadores PtRuNi/C

3.2. Caracterização físico-química dos eletrocatalisadores PtRuNi/C

3.3. Eletrooxidação de metanol

\section{RESULTADOS E DISCUSSÕES}

4.1. Preparação dos eletrocatalisadores PtRuNi/C pelo método da redução por álcool

4.2. Preparação dos eletrocatalisadores $P t R u N i / C$ pelo metodo de redução por álcool de redução por álcool em meio alcalino.

4.3 Preparação de eletrocatalisadores PtRuNi/C com diferentes razôes 
atômicas Pt:Ru:Ni.

4.4. Preparação do eletrocatalisador PtRuNi/C (50:40:10) variando a razão $\mathrm{OH}^{-} /$metais.

5. CONCLUSÕES 46

6. TRABALHOS FUTUROS 48

7. REFERÊNCIAS BIBLIOGRAFICAS 49 


\section{LISTA DE FIGURAS}

FIGURA 1 - Desenho esquemático de uma célula a combustivel unitária

FIGURA 2 - Esquema simplificado de uma célula a combustivel.

FIGURA 3 - Esquema do processo de síntese dos eletrocatalisadores.

FIGURA 4 - Diagrama esquemático do eletrodo de camada fina porosa.

FIGURA 5 - Representação esquemática da célula eletroquímica usada para realização das medidas de voltametria e cronoamperometria e por eletrodo de camada fina porosa.

FIGURA 6 - Espectros dos eletrocatalisadores PtRu/C (50:50) E-TEK e PtRu/C (50:50) preparados pelo método de redução por álcool.

FIGURA 7 - Análises Terr uyravimetricas PtRu/C, temperatura ambiente até $1000{ }^{\circ} \mathrm{C}$, com uma taxa de aquecimento igual a $5{ }^{\circ} \mathrm{C} \cdot \mathrm{min}^{-1} \mathrm{em}$ atmosfera de oxigênio seco (30 mL. $\left.\mathrm{min}^{-1}\right)$.

FIGURA 8 - Difratogramas de raios $X$ dos eletrocatalisadores PtRu/C e PtRuNi/C.

FIGURA 9 - Voltamogramas cíclicos obtidos em solução $0,5 \mathrm{~mol} . \mathrm{L}^{-1}$ de $\mathrm{H}_{2} \mathrm{SO}_{4}$ para os eletrocatalisadores PtRu/C E-TEK, PtRu/C e PtRuNi/C preparados pelo método da redução por álcool.

FIGURA 10 - Comparação dos valores de corrente para PtRu/C e PtRuNi/C preparados pelo método da redução por álcool na presença de $1,0 \mathrm{~mol} \cdot \mathrm{L}^{-1}$ de metanol, considerando-se apenas a varredura anódica, sendo esta corrigida pelo voltamograma base.

FIGURA î́ - Comparação das curvas cronoamperométricas para os catalisadores PtRu/C e PtRuNi/C com potencial fixo de $500 \mathrm{mV}$ por $30 \mathrm{~min} .26$ FIGURA 12 - Espectro do eletrocatalisador PtRuNi/C (50:40:10) preparado pelo método de redução por álcool utilizando uma razâo molar $\mathrm{OH}^{-} / \mathrm{Me}=8$.

FIGURA 13 - Análises Termogravimetricas PtRu/C e PtRuNi/C preparadas em meio alcalino, temperatura ambiente até $900{ }^{\circ} \mathrm{C}$, com uma taxa de aquecimento igual a $5^{\circ} \mathrm{C} \cdot \mathrm{min}^{-1} \mathrm{em}$ atmosfera de oxigênio seco $(30 \mathrm{~mL} \cdot \mathrm{min}$ $\left.{ }^{1}\right)$.

FIGURA 14 - Difratogramas de raios $X$ dos eletrocatalisadores PtRu/C e 
FIGURA 15 - Voltamogramas cíclicos obtidos em solução $0,5 \mathrm{~mol} . \mathrm{L}^{-1}$ de $\mathrm{H}_{2} \mathrm{SO}_{4}$ para os eletrocatalisadores PtRu/C E-TEK, PtRu/C e PtRuNi/C preparados pelo método da redução por álcool.

FIGURA 16 - Comparação dos valores de corrente para PtRu/C e PtRuNi/C preparados pelo método da redução por álcool na presença de $1 \mathrm{~mol} \cdot L^{-1}$ de metanol, considerando-se apenas a varredura anódica, sendo esta corrigida pelo voltamograma base.

FIGURA 17 - Comparação das curvas cronoamperométricas para os catalisadores PtRu/C e PtRuNi/C corn potencial fixo de $500 \mathrm{mV}$ por $30 \mathrm{~min}$.

FIGURA 18 - Análises Termogravimétricas PtRu/C, temperatura ambiente até $900^{\circ} \mathrm{C}$, com uma taxa de aquecimento igual a $5^{\circ} \mathrm{C} \cdot \mathrm{min}^{-1} \mathrm{em}$ atmosfera de oxigênio seco (30 mL.min $\left.{ }^{-1}\right)$.

FIGURA 19 - Difratogramas de raios $X$ dos eletrocatalisadores PtRuNi/C preparados pelo método de redução por álcool com diferentes razões atômicas.

FIGURA 20 - Comparação dos valores de corrente para PtRu E-TEK e PtRuNi/C preparados pelo método da redução por álcool na presença de 1 $\mathrm{mol} \cdot \mathrm{L}^{-1}$ de metanol, considerando-se apenas a varredura anódica, sendo esta corrigida pelo voltamograma base.

FIGURA 21 - Comparação das curvas cronoamperométricas para os catalisadores PtRu E-TEK e PtRuNi/C com potencial fixo de $500 \mathrm{mV}$ por $30 \mathrm{~min}$.

FIGURA 22 - Micrografia eletrônica de transmissão do eletrocatalisador PtRuNi/C 50:40:10 preparado com razão $\mathrm{OH}^{-} / \mathrm{Me}=8$.

FIGURA 23 - Análises Termogravimétricas PtRu/C, temperatura ambiente até $900{ }^{\circ} \mathrm{C}$, com uma taxa de aquecimento igual a $5^{\circ} \mathrm{C} \cdot \mathrm{min}^{-1} \mathrm{em}$ atmosfera de oxigênio seco (30 mL. $\left.\mathrm{min}^{-1}\right)$.

FIGURA 24 - Difratogramas de raios $X$ dos eletrocatalisadores PtRuNi/C 50:40:10 preparado com diferentes razôes $\mathrm{OH}^{2} /$ metais.

FIGURA 25 - Voltamogramas cíclicos obtidos em solução $0.5 \mathrm{~mol}^{-1} \mathrm{~L}^{-1}$ de $\mathrm{H}_{2} \mathrm{SO}_{4}$ para o eletrocatalisadore PtRuNi/C preparados pelo método da redução por álcool. 
FIGURA 27 - Comparação das curvas cronoamperométricas para os catalisadores PtRuNi/C variando o $\mathrm{pH}$ do meio reacional com potencial fixo de $500 \mathrm{mV}$ por $30 \mathrm{~min}$. 


\section{LISTA DE TABELAS}

TABELA 1. Razão atômica e tamanho médio de cristalito de partículas dos eletrocatalisadores PtRu/C e PtRuNi/C preparados pelo método da redução por álcool.

TABELA 2. Razão atômica e tamanho médio de cristalinos dos eletrocatalisadores PtRu/C e PtRuNi/C preparados pelo método da redução por álcool utilizando uma razão molar $\mathrm{OH}^{-} /$metais $=8$.

TABELA 3. Razão atômica e tamanho médio de cristalito dos eletrocatalisadores PtRuNi/C preparados pelo método da redução por álcool com diferențas razôes atômicas Pt:Ru:Ni (razão molar $\mathrm{OH}^{-} 34$ /metais=8).

TABELA 4 - Razão atômica e tamanho médio de cristalitos dos eletrocatalisadores PtRuNi/C 50:40:10 variando a razão $\mathrm{OH}^{-} /$metais. 


\section{INTRODUÇÃO}

\subsection{Células a combustivel}

Os problemas ambientais, como o efeito estufa, a chuva ácida e os altos indices de problemas pulmonares e cardiovasculares, causados pela contaminação do ar em grandes centros urbanos, são motivos importantes para o desenvolvimento e melhora de sistemas mais eficientes e menos poluentes de geração de energia [1]. Entre esses sistemas destacam-se as células a combustivel.

As células a combustivel FIG. 1 são dispositivos que convertem energia química diretamente em energia elétrica, da mosma forma que as pilhas e as baterias em geral. Porém, uma diferença fundamental entre as baterias convencionais e as células a combustivel é que nestas últimas os componentes da reação de oxido-redução (combustivel e o oxidante) não se encontram em seu interior, mas sāo alimentados externamente. Nas células, o combustivel oxida-se continuamente em um dos eletrodos (ânodo), enquanto reduz-se oxigênio no outro eletrodo (cátodo). A reação completa-se com a circulação dos elétrons, através do circuito externo, que realiza o trabalho elétrico [2]. Atualmente, o combustivel que apresenta o maior interesse prático é o hidrogênio. Desta forma, ao se dispor de combustiveis como o gás natural, metanol, etanol, biogás, etc., o procedimento usual consiste em submetê-los a um processo de reforma com vapor e a finalidade é obter hidrogênio para introduzi-lo posteriormente na célula. Atualmente o processo de reforma com vapor do gás natural é amplamente utilizado para a produção de hidrogênio, o qual é principalmente usado na fabricação de fertilizantes [2]. 


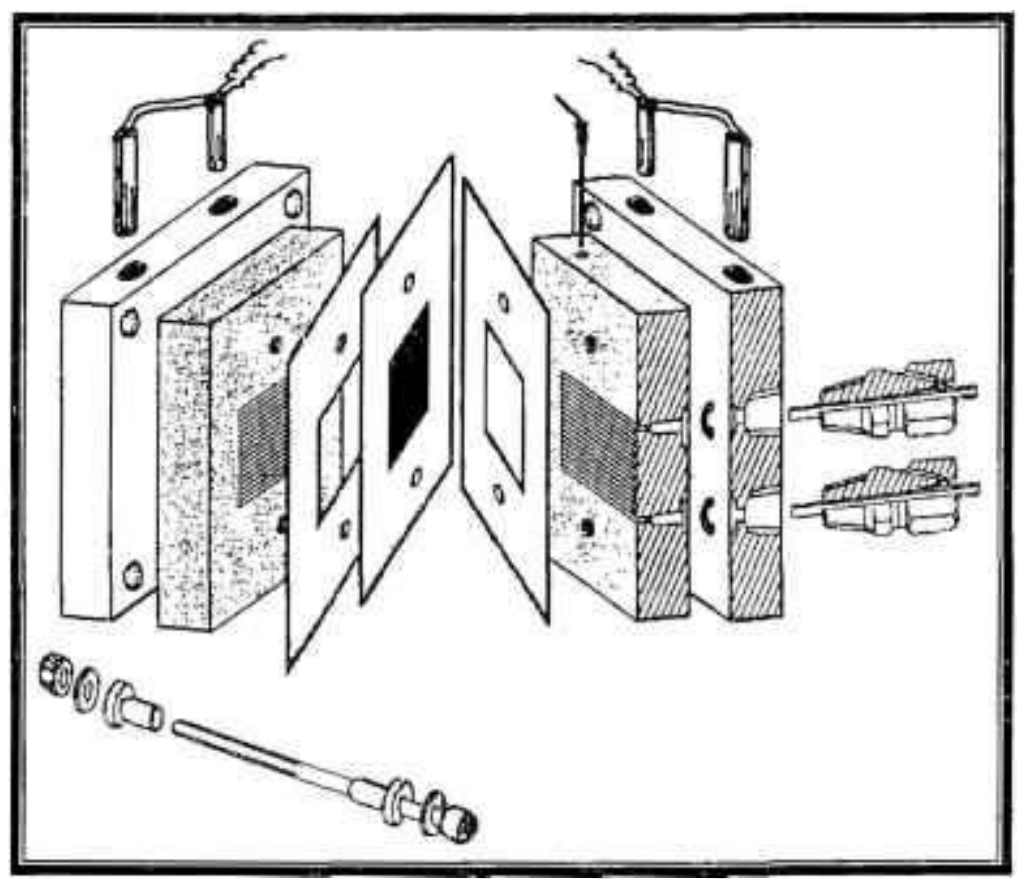

Figura 1 - Desenho esquemático de uma célula a combustivel unitária [3].

Embora os estudos iniciais sobre células a combustivel tenham sido feitos há mais de cem anos, as suas aplicações práticas começaram ser consideradas há pouco mais de quarenta anos. Desde 1960, as células a combustivel são utilizadas com sucesso no programa espacial norteamericano, incluindo os projetos Gemini, Apollo e Space Shuttle. Nos veículos espaciais as células trabalham com hidrogênio puro como combustivel e tem sido preferida à outras fontes de energia pela sua elevada densidade de potência e por ter como produto da reação água potável, a qual é aproveitada pelos astronautas. A partir de 1973, principalmente por causa da crise do petróleo, surgiu um enorme interesse nas aplicações terrestres destes sistemas, devido principalmente sua alta eficiência energética (conversão de energia química diretamente em elétrica) quando comparado às máquinas térmicas. Pode-se dizer que nas décadas dos anos 70 e 80 do século passado, a busca pelo aumento da eficiência energética foi um fator determinante do progresso alcançado no campo das células a combustivel $[4,5]$.

Apesar das perspectivas pessimistas em relação ao petróleo não se concretizarem em curto prazo, surgiu a consciência de que o petróleo deveria ser utilizado para fins mais nobres e não ser, simplesmente, queimado. 
Recentemente a necessidade de medidas urgentes para proteger o meio ambiente tem crescido sem precedentes, o qual aumentou ainda mais o interesse nas células a combustivel, pois, em contraste com as máquinas térmicas, são conversores de energia essencialmente limpos. Isto significa que, por um lado, as células a combustível podem instalar-se sem prejuizos ambientais em zonas com alta densidade populacional e ainda, evitam o alto custo de instalação de linhas de transmissão de eletricidade em grandes distâncias para $O$ abastecimento de núcleos isolados. É importante destacar também que as células a combustivel empregam poucos dispositivos com partes móveis. Isto significa não somente um baixo nível de ruído em operação (baixa poluição sonora), como também uma baixa necessidade de manutenção. Neste sentido as células a combustível também superam as máquinas térmicas $[1,4,5]$.

Por estas razões atualmente existe um enorme interesse em promovar a aplicação das células a combustível como sistemas autônomos de produção de energia elétrica, no entanto, as células a combustível apresentam ainda um custo bastante elevado, no caso das células a combustível de eletrólito polimérico sólido (Proton Exchange Membrane Fuel Cell-PEMFC) a platina, utilizada nos eletrocatalisadores, e a membrana (eletrólito) representam uma porcentagem significativa deste custo [6].

\subsection{Células a combustível de eletrólito polimérico sólido (PEMFC)}

Nas células PEMFC FIG. 2 o eletrólito consiste em uma membrana polimérica trocadora de prótons (geralmente Nafion, produzida por Du Pont), o qual é um polímero perfluorado com grupamentos sulfônicos. A principal função da membrana é permitir a condução dos íons $\mathrm{H}^{+}$do ânodo para o cátodo. Para que a condução protônica ocorra, a membrana deve estar hidratada, assim as células tipo PEMFC apresentam temperatura de operação de até $100^{\circ} \mathrm{C}$. Como ânodo e cátodo são utilizados os eletrodos de difusão de gás (EDG), os quais são constituidos por uma camada catalítica formada por nanopartículas de platina suportadas em carbono, além de uma camada difusora constituída por uma mistura de politetrafluoretileno (PTFE) e carbono finamente dividido depositada em uma estrutura de carbono (tecido ou papel). 


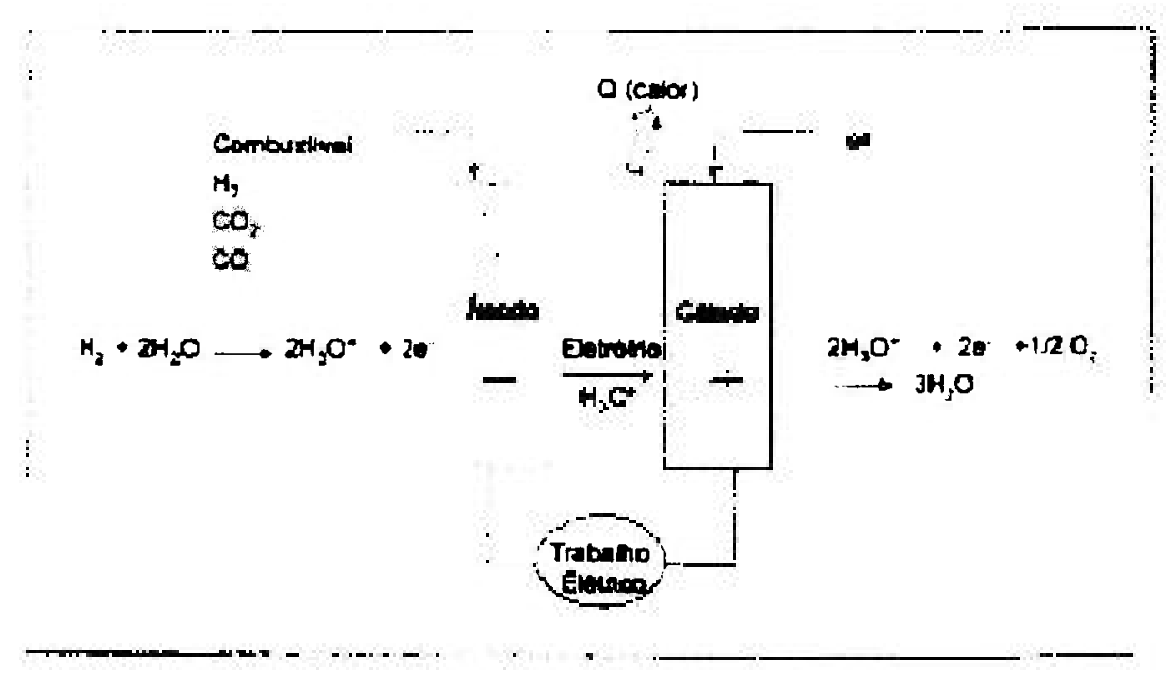

FIGURA 2. - Esquema simplificado de uma célula a combustivel [7].

A PEMFC é alimentada com hidrogênio no ânodo o qual é oxidado a prótons e elétrons Eq. 1, os elétrons percorrem um circuito externo, enquanto que, os prótons atravessam a membrana até o compartimento catódico, onde 0 oxigênio do ar atmosférico é reduzido Eq. 2 [2,7]. Dessa forma, uma corrente elétrica é gerada e $\mathrm{H}_{2} \mathrm{O}$ Eq 3 é formada como produto.

Ânodo:

$$
\mathrm{H}_{2}+2 \mathrm{H}_{2} \mathrm{O} \leftrightarrow 2 \mathrm{H}_{3} \mathrm{O}^{+}+2 \mathrm{e}^{-}
$$

Equação 1

Cátodo:

$$
2 \mathrm{e}^{*}+2 \mathrm{H}_{3} \mathrm{O}^{+}+1 / 2 \mathrm{O}_{2} \rightarrow 3 \mathrm{H}_{2} \mathrm{O}
$$

Equação 2

Reação global:

$$
\mathrm{H}_{2}+1 / 2 \mathrm{O}_{2} \leftrightarrow \mathrm{H}_{2} \mathrm{O}
$$

Equação 3

O oxigênio pode ser obtido diretamente do ar atmosférico, enquanto a forma mais barata de obter o hidrogênio é através do processo de reforma catalítica de um combustivel primário rico em hidrogênio (renovável ou não). Neste processo, certa quantidade de monóxido de carbono é formada como subproduto da reação. A presença de monóxido de carbono no hidrogênio leva ao envenenamento da platina, pois é adsorvido fortemente nos sítios ativos, 
desfavorecendo a adsorção e, conseqüentemente, a reação de oxidação do $\mathrm{H}_{2}$. Desse modo, alguns ppm de $\mathrm{CO}$ (> $10 \mathrm{ppm}$ ) na alimentação de hidrogênio levam a uma queda no desempenho da célula em mais de $80 \%$. Uma alternativa para contornar este problema é adicionar um segundo metal à platina (co-catalisador), por exemplo, o rutênio, o qual leva à formação de espécies oxigenadas em potenciais inferiores a $0,25 \mathrm{~V}$, facilitando a oxidação do $\mathrm{CO}$ a $\mathrm{CO}_{2}$. Quando se utiliza somente platina, as espécies oxigenadas são formadas em potenciais acima de $0,7 \mathrm{~V}$, diminuindo a eficiência do processo [78]. O hidrogênio apresenta ainda alguns inconvenientes operacionais e de infra-estrutura. A compressão, o armazenamento e a distribuição do hidrogênio requerem tecnologias relativamente sofisticadas e de custo elevado, o que dificulta o uso deste combustivel, particularmente em certas aplicações que seriam de grande impacto, como na utilização em veículos e em equipamentos portáteis. Devido a esta constatação, têm surgido esforços significativos para desenvolver células a combustivel que possam operar diretamente com combustiveis liquidos [7-8].

\subsection{Célula a combustivel utilizando metanol diretamente como combustivel (Direct Methanol Fuel Cell - DMFC)}

O metanol tem sido utilizado diretamente como combustível em células de eletrólito polimérico sólido, sendo chamadas neste caso DMFC [9]. Esta célula é alimentada com metanol na forma de vapor ou liquido e opera a temperaturas menores que $100{ }^{\circ} \mathrm{C}$. Idealmente as reações que ocorrem em células a metanol direto são Eq. 4-6:

$$
\begin{array}{lll}
\text { ânodo: } \mathrm{CH}_{3} \mathrm{OH}+\mathrm{H}_{2} \mathrm{O} \leftrightarrow \quad \mathrm{CO}_{2}+\mathrm{H}^{+}+6 \mathrm{e}^{-} & \text {Equação } 4 \\
\text { cátodo: } 3 / 2 \mathrm{O}_{2}+6 \mathrm{e}^{-}+6 \mathrm{H}^{+} \leftrightarrow 3 \mathrm{H}_{2} \mathrm{O} & \text { Equação } 5
\end{array}
$$

Reação global: $\mathrm{CH}_{3} \mathrm{OH}+3 / 2 \mathrm{O}_{2} \leftrightarrow \quad \mathrm{CO}_{2}+2 \mathrm{H}_{2} \mathrm{O} \quad$ Equação 6 
A reação de eletrooxidaçăo completa do metanol produz 6 elétrons e o potencial padrão da $\operatorname{DMFC}(1,20 \mathrm{~V})$ não é muito diferente do potencial da PEMFC alimentada com $\mathrm{H}_{2}(1,23 \mathrm{~V})$. Entretanto, a reação é bastante lenta, como resultado da formação de intermediários fortemente adsorvidos, tais como o monóxido de carbono $\left(\mathrm{CO}_{\mathrm{ads}}\right)$, resultando em potenciais operacionais bem menores. A oxidação desses intermediários a $\mathrm{CO}_{2}$ requer a participação de espécies que contem oxigênio $\left(\mathrm{OH}, \mathrm{H}_{2} \mathrm{O}\right)$, que devem ser adsorvidas também nos sítios ativos do catalisador. A platina sozinha não é suficientemente ativa para a oxidação do $\mathrm{CO}_{\text {ads }}$ a $\mathrm{CO}_{2}$ porque, como mencionado acima, essas espécies se formam em potenciais relativamente elevados. Por isso, na presença de CO é necessário o uso de segundo metal, normalmente rutênio, o qual forma espécies oxigenadas em potenciais mais baixos que as formadas nos sitios de platina e facilitam a oxidação do $\mathrm{CO}_{\mathrm{ads}}$ nos sítios de platina, através do chamado mecanismo bifuncional $[9$ e referências citadas].

\subsection{Mecanismo da Oxidação do Metanol sobre Platina e Platina-Rutênio}

As reaçōes da oxidação do metanol foram objetos de vários estudos do passado $[9,10]$. Foram propostos vários mecanismos para a oxidação anódica do metanol, envolvendo várias etapas, nas quais ocorre a formação de intermediários, como por exemplo, formaldeido, ácido fórmico e monóxido de carbono (CO). A existência destes intermediários é comprovada por várias técnicas, mas o que não se sabe com detalhes é a rota pela qual a reação acontece. Um possivel mecanismo para a reação de oxidação do metanol [11] é mostrado a seguir:

Observa-se que as reações mostradas Eq. $7-10$ são processos de eletrosorção, enquanto que, as reações seguintes Eq. 11-13 envolvem transferência de oxigênio para a oxidação dos intermediários ligados à superficie [9-11].

$$
\begin{array}{ll}
\mathrm{CH}_{3} \mathrm{OH}+\mathrm{Pt}(\mathrm{s}) \leftrightarrow \mathrm{Pt}-\mathrm{CH}_{2} \mathrm{OH}_{\mathrm{ads}}+\mathrm{H}^{+}+\mathrm{e}^{-} & \text {Equação } 7 \\
\mathrm{Pt}-\mathrm{CH}_{2} \mathrm{OH}_{\mathrm{ads}}+\mathrm{Pt}_{(\mathrm{s})} \leftrightarrow \mathrm{Pt}_{2}-\mathrm{CHOH}_{\mathrm{ads}}+\mathrm{H}^{+}+\mathrm{e}^{-} & \text {Equação 8 }
\end{array}
$$




$$
\begin{array}{ll}
\mathrm{Pt}_{2}-\mathrm{CHOH}_{\mathrm{ads}}+\mathrm{Pt}(\mathrm{s}) \leftrightarrow \mathrm{Pt}_{3}-\mathrm{COH}_{\mathrm{ads}}+\mathrm{H}^{+}+\mathrm{e}^{-} & \text {Equação } 9 \\
\mathrm{Pt}_{3}-\mathrm{COH}_{\mathrm{ads}} \leftrightarrow \mathrm{Pt}-\mathrm{CO}_{\mathrm{ads}}+2 \mathrm{Pt}(\mathrm{s})+\mathrm{H}^{+}+\mathrm{e}^{-} & \text {Equação 10 } \\
\mathrm{Pt}(\mathrm{s})+\mathrm{H}_{2} \mathrm{O} \leftrightarrow \mathrm{Pt}-\mathrm{OH}_{\mathrm{ads}}+\mathrm{H}^{+}+\mathrm{e}^{-} & \text {Equação 11 } \\
\mathrm{Pt}-\mathrm{CO}_{\mathrm{ads}}+\mathrm{H}_{2} \mathrm{O} \leftrightarrow \mathrm{Pt}-\mathrm{COOH}_{\mathrm{ads}}+\mathrm{H}^{+}+\mathrm{e}^{-} & \text {ou } \\
\mathrm{Pt}-\mathrm{OH}_{\mathrm{ads}}+\mathrm{Pt}-\mathrm{CO}_{\mathrm{ads}} \leftrightarrow \mathrm{Pt}_{-} \mathrm{COOH}_{\mathrm{ads}} & \text { Equação 12a } \\
\mathrm{Pt}-\mathrm{COOH}_{\mathrm{ads}} \leftrightarrow \mathrm{Pt}_{(\mathrm{s})}+\mathrm{CO}_{2}+\mathrm{H}^{+}+\mathrm{e}^{-} & \text {Equãa 12b }
\end{array}
$$

De ido ao envenenamento que ocorre pela adsorção do $\mathrm{CO}$, a platina não é suficientemente ativa para ser usada eficientemente na eletrooxidação do metanol. Para resolver este problema, uma alternativa para favorecer a oxidação dos intermediários, como o $\mathrm{CO}$, é a incorporação de um segundo metal, formando eletrocatalisadores que sejam capazes de formar espécies oxigenadas a potenciais menores que a platina, facilitando assim a oxidação do $\mathrm{CO}_{\text {ads }}$ a $\mathrm{CO}_{2}$ [12]. Este mecanismo é chamado de mecanismo bifuncional e foi proposto por Watanabe et al. [13]. O catalisador bimetálico que têm apresentado melhores resultados para $\circ$ uso em células a combustivel de metanol direto (DMFC) utiliza platina e rutênio como metais [14].

Os eletrocatalisadores a base de PtRu na forma de ligas e/ou com o rutênio na forma de óxidos atuam através do mecanismo bifuncional e/ou do efeito eletrônico $[9,15-17]$.Pelo mecanismo bifuncional um eletrocatalisador efetivo na eletrooxidação do metanol deve conter, no mínimo, dois tipos de elementos superficiais, um que adsorva o metanol e atue na quebra das ligações $\mathrm{C}-\mathrm{H}$, e outro que adsorva e ative as moléculas de água a fim de produzir espécies oxigenadas adsorvidas, em sítios vizinhos aos sitios da Pt. Atualmente, sabe-se que o elemento mais ativo na adsorção do metanol, na temperatura e potencial de operação de uma DMFC, é a platina e o elemento mais ativo na adsorção da água, nas mesmas condições, é o rutênio [14]. A seguir sāo mostradas as reaçōes do mecanismo bifuncional Eq. 14-18 [9,17]. 


$$
\begin{array}{ll}
\mathrm{CH}_{3} \mathrm{OH}+\mathrm{Pt}\left(\mathrm{H}_{2} \mathrm{O}\right) \leftrightarrow \mathrm{Pt}\left(\mathrm{CH}_{3} \mathrm{OH}\right)_{\text {ads }}+\mathrm{H}_{2} \mathrm{O} & \text { Equação } 14 \\
\mathrm{Pt}\left(\mathrm{CH}_{3} \mathrm{OH}\right)_{\text {ads }} \leftrightarrow \mathrm{Pt}(\mathrm{CO})_{\text {ads }}+4 \mathrm{H}^{+}+4 \mathrm{e}^{-} & \text {Equação } 15 \\
\mathrm{Ru}\left(\mathrm{H}_{2} \mathrm{O}\right) \leftrightarrow \mathrm{RuOH}+\mathrm{H}^{+}+\mathrm{e}^{-} & \text {Equação } 16 \\
\mathrm{Pt}(\mathrm{CO})_{\text {ads }}+\mathrm{RuOH} \leftrightarrow \mathrm{Pt}+\mathrm{Ru}+\mathrm{CO}_{2}+\mathrm{H}^{+}+\mathrm{e}^{-} & \text {Equação } 17 \\
\mathrm{Ru}(\mathrm{CO})_{\text {ads }}+\mathrm{RuOH} \leftrightarrow 2 \mathrm{Ru}+\mathrm{CO}_{2}+\mathrm{H}^{+}+\mathrm{e}^{-} &
\end{array}
$$

Dessa forma, a platina e o rutênio atuam de forma completar possibilitando a eletrooxidação do metanol a baixos potenciais [9].

\subsection{Método da redução por álcool}

O método da redução por álcool foi desenvolvido por Toshima e Yonezawa [18], para preparar dispersōes coloidais de nanopartículas apresentando tamanho e distribuições bem uniformes. Neste método, o refluxo de uma solução alcoólica contendo o ion metálico na presença de um agente estabilizante, normaimente um polímero, fornece dispersões coloidais homogêneas das nanopartículas metálicas correspondente. $O$ álcool funciona como solvente e agente redutor, sendo oxidado à aldeídos e/ou cetonas Eq. 19.

$$
\mathrm{H}_{2} \mathrm{PtCl}_{6}+2 \mathrm{CH}_{3} \mathrm{OH} \leftrightarrow \quad \mathrm{Pt}+2 \mathrm{HCHO}+6 \mathrm{HCl} \quad \text { Equação } 19
$$

Este método apresenta as seguintes vantagens: i) o procedimento é muito simples e reprodutivel, ii) as nanopartículas obtidas são pequenas e apresentam-se bem distribuídas, iii) o tamanho das nanopartículas pode ser controlado alterando as condiçōes de preparação, como escolha do álcool (metanol, etanol, 2-propanol, glicóis e etc), temperatura de reação, quantidade e variedade do agente estabilizante, concentração do íon metálico e uso de 
aditivos, iv) as dispersões coloidais das nanopartículas apresentam alta atividade catalítica e v) as dispersões obtidas são bastante estáveis [18,19].

\subsubsection{Método da redução por álcool na preparação de eletrocatalisadores Pt/C e PtRu/C}

O método da redução por álcool foi testado por Wang e Hsing [20] na preparação de eletrocatalisadores Pt/C e PtRu/C. Para isto, uma solução metanol-água contendo os sais de platina e de rutênio foi refluxada na presença de um agente estabilizante (surfactante SB12) e do suporte de carbono. As análises por DRX, TEM e XPS mostraram que as nanopartículas (tamanho médio de 2,5 nm) apresentavam-se bem dispersas e suportadas no carbono. A caracterização eletroquímica mostrou que, em comparação ao eletrocatalisador comercial da·ETEK, o eletrocatalisador Pt/C apresentou atividade catalítica similar para a reação de redução de oxigênio, enquanto que o eletrocatalisador PtRu/C apresentou maior tolerância ao envenenamento pelo monóxido de carbono.

Lee e colaboradores [21] prepararam o eletrocatalisador $\mathrm{Pt} / \mathrm{C}$ pelo método da redução por álcool. Uma solução aquosa de $\mathrm{H}_{2} \mathrm{PtCl}_{6} \cdot 6 \mathrm{H}_{2} \mathrm{O}$ foi adicionada ao álcool e uma pequena quantidade de solução aquosa de $\mathrm{KOH}$ foi adicionada gota a gota. Uma razão molar $\mathrm{KOH} / \mathrm{Pt}=8$ foi usada para induzir a formação de nanoparticulas pequenas e bem uniformes. O suporte de carbono foi disperso nesta solução usando ultra-som e a mistura resultante foi aquecida em forno de microondas por $60 \mathrm{~s}$. A suspensão resultante foi filtrada, lavada com acetona e seca. As medidas por EDX indicaram a incorporação de 9,5; 13,6 e $18,6 \%$ em massa para as amostras preparadas a partir de 10,15 e $20 \%$ em massa de platina. Os eletrocatalisadores Pt/C obtidos apresentaram um melhor desempenho que o eletrocatalisador Pt/C E-TEK na oxidação do metanol a temperatura ambiente.

\subsubsection{Método de redução por álcool desenvolvido no IPEN-CNEN/SP}

Em 2003 foi desenvolvido no IPEN-CNEN/SP um método de preparaçāo de eletrocatalisadores (nanoparticulas a base de Pt suportadas em carbono) 
pelo método de redução por álcool $[22,23]$. Os eletrocatalisadores PtRu/C foram preparados na ausência de agentes estabilizantes e/ou ajustes de $\mathrm{pH}$ do meio reacional. Neste caso a platina $\left(\mathrm{H}_{2} \mathrm{PtCl}_{6} .6 \mathrm{H}_{2} \mathrm{O}\right)$ e o rutênio $\left(\mathrm{RuCl}_{3} .1,5 \mathrm{H}_{2} \mathrm{O}\right)$ foram dissolvidos em uma mistura de etileno glicol/água $(3 / 1, v / v)$ e o suporte de carbono foi adicionado a esta solução. A mistura de carbono resultante foi submetida a refluxo sob agitação e após foi filtrada, lavada com água e seca [23]. O material preparado apresentou uma boa distribuição das nanoparticulas sobre o suporte de carbono e foi mais ativo na eletrooxidação do etanol que do eletrocatalisador comercial PtRu/C E-TEK [22].

Posteriormente, foram preparados por esta metodologia eletrocatalisadores $\mathrm{PtSn} / \mathrm{C}, \mathrm{PtSnRh} / \mathrm{C}, \mathrm{PtSnRu} / \mathrm{C}, \mathrm{PtSnNi} / \mathrm{C}$, os quais também apresentaram uma boa atividade catalítica na eletrooxidação de álcoois, como metanol, etanol e o etileno glicol [24-28].

\subsection{Preparação de eletrocatalisadores PtRuNi/C para a eletrooxidação de metanol.}

Ultimamente diversos estudos têm mostrado que a atividade dos eletrocatalisadores PtRu é bastante influenciada pelo método de preparação e que a adição de um terceiro ou quarto elemento a estes eletrocatalisadores os tornam mais ativos na eletrooxidação do metanol [29,30].

Park et al. [31] prepararam nanoparticulas metálicas Pt. PtRu (50:50), PtNi (25:75), e PtRuNi (50:40:10) na forma de ligas usando $\mathrm{NaBH}_{4}$ como agente redutor e testaram os materiais obtidos na eletrooxidação do metanol em solução $\mathrm{H}_{2} \mathrm{SO}_{4}$. A seguinte ordem foi verificada para o potencial de início de oxidação do metanol: PtRuNi (50:40:10) < PtRu (50:50) < PtNi (50:50) < Pt/Ni $(75: 25)<$ Pt. Os dados de XPS confirmaram que o Ni e o Ru existem na forma de metais e óxidos, sendo que para o $\mathrm{Ni}$ estas espécies incluem $\mathrm{Ni}$, $\mathrm{NiO}$, $\mathrm{Ni}(\mathrm{OH})_{2}$ e $\mathrm{NiOOH}$. Na análise por XPS para a $\mathrm{Pt}$ foi identificado um deslocamento na energia de ligação, o qual foi interpretado como uma modificação eletrônica da estrutura da Pt através da transferência de elétrons do Ni para a Pt. O início da oxidação do metanol a potenciais menores e os maiores valores de corrente obtidos para eletrocatalisadores PtRuNi (50:40:10), quando comparado ao catalisador PtRu (50:50), foram atribuidos, então, a 
transferência eletrônica do Ni para a $\mathrm{Pt}$, facilitando a oxidação do $\mathrm{CO}$, o qual é formado na decomposição do metanol, e também à formação de espécies óxidos de $\mathrm{Ni}$ que facilitam a oxidação do $\mathrm{CO}$ através do mecanismo bifuncional. Também vale ressaltar que os autores não observaram a dissolução de $\mathrm{Ni}$ no meio ácido na faixa de potencial estudada $0 \sim 1,6 \vee(E R H)$. Os autores atribuiram isso à estabilização do Ni pela rede de $\mathrm{Pt}$.

Wang et al. [33] prepararam eletrocatalisadores Pt/C PtRu/C e PtRuNi/C através da redução química com $\mathrm{NaBH}_{4}$ (borohidreto de sódio) dos precursores $\mathrm{H}_{2} \mathrm{PtCl}_{6}, \mathrm{RuCl}_{3}$ e $\mathrm{NiCl}_{2}$ a $80^{\circ} \mathrm{C}$. Os potenciais de início de oxidação foram similares para os eletrocatalisadores PtRuNi/C (60:30:10) e PtRu/C (50:50), no entanto, o catalisador PtRuNi/C apresentou maiores valores de corrente na faixa estudada, sendo que a área ativa dos eletrocatalisadores eram praticamente as mesmas. Foi realizado também um estudo da atividade em relação a razão atômica $\mathrm{Pt}: \mathrm{Ru}$ : Ni e o melhor valor encontrado foi de 60:30:10 para eletrooxidação de metanol. A melhor atividade do catalisador PtRuNi/C em relação a PtRu/C foi atribuido ao efeito eletrônico, ou seja, transferência de eletróns do Ni para a $\mathrm{Pt}$, o que pode contribuir para uma menor força de ligação $\mathrm{Pt}-\mathrm{CO}$, e também à espécies de $\mathrm{Ni}$ oxigenadas existentes na superficie, tais como $\mathrm{Ni}(\mathrm{OH})_{2}$ e $\mathrm{NiOOH}$, as quais favorecem o mecanismo bifuncional. Comparado a $\mathrm{Pt}$, os picos de difração de raios $X$ do catalisador $\mathrm{PtRu} / \mathrm{C}$ e PtRuNi/C encontravam-se deslocados para maiores valores de $2 \theta$. Este deslocamento foi atribuido à incorporação de átomos de rutênio e niquel na estrutura cúbica da fase centrada (CFC) da Pt. Não foram observados picos que indicassem a presença de fases puras de Ru e Ni ou da fase hexagonal (hcp) rica em rutênio ou de óxidos de niquel. Os autores atribuiram às espécies de diferentes óxidos de níquel presentes na superfície do catalisador propriedades favoráveis como a condutividade protônica e eletrônica, bem como, a proteção da corrosão nas condições eletrooxidação do metanol.

Martinez-Huerta et al. [34] prepararam os eletrocatalisadores $\mathrm{Pt} / \mathrm{C}$, PtRu/C, PtNi/C e PtRuNi/C pelos métodos: a) coloidal, utilizando um método similar ao descrito por Watanabe para preparação de PtRu/C, e b) microemulsão utilizado hidrazina como agente redutor. Foi observado que o $\mathrm{Ni}$ modificou o comportamento dos eletrocatalisadores na reação de oxidação de 
CO e de metanol. Para os eletrocatalisadores PtRuNi/C praticamente não foi detectada a presença de $\mathrm{Ni}$ na superfície das nanoparticulas pela análise por XPS. Para as amostras PtNi/C preparadas por microemulsão a análise por XPS revelou quantidades de $\mathrm{Pt}$ e $\mathrm{Ni}$ próxima as nominais e a presença de quantidades relativamente altas de espécies $\mathrm{Ni}(15 \%)$, sendo as outras espécies detectadas $\mathrm{NiO}, \mathrm{Ni}(\mathrm{OH})_{2}$ e $\mathrm{NiOOH}$. Assim, a energia de ligação da $\mathrm{Pt}$ $4 \mathrm{f}$ encontrava-se delocada para valores mais baixos quando $\mathrm{Ni}$ era detectado. Este comportamento não foi observado para amostras onde $\mathrm{Ni}$ não foi detectado.ou para a amostra Pt/C preparada por microemulsão. Portanto, os autores concluíram que a presença de $\mathrm{Ni}$ modificou a densidade eletrônica da $\mathrm{Pt}$, especialmente para as amostras preparadas por microemulsão. Foi observado também uma maior atividade na oxidação do CO para os eletrocatalisadores $\mathrm{PtNi} / \mathrm{C}$, quando comparados a $\mathrm{Pt}$, do que o observado para a eletrocatalisadores PtRuNi/C, quando comparadj ao PtRu/C. Assim, na oxidação do $\mathrm{CO}$ o efeito promocional do $\mathrm{Ni}$ foi atribuido principalmente à interação eletrônica Pt-Ni ao invés da habilidade destas amostras de formar especies $\mathrm{OH}$. Na eletrooxidação de metanol os eletrocatalisadores PtRuNi/C apresentaram-se mais ativos que PtRu/C e Pt/C. Apesar da interação eletrônica Pt-Ni não ser totalmente descartada nos eletrocatalisadores PtRuNi/C, a maior atividade na eletrooxidação do metanol foi atribuída às espécies de Ni em companhia de Ru na proporção adequada, o que facilitaria a formação de espécies $\mathrm{OH}$. Os autores observaram também que a liga $\mathrm{Pt}-\mathrm{Ni}$ não é estável em toda a faixa de potencial, sendo o Ni removido da superficie da amostra quando ciclado além de $1 \mathrm{~V}$ (Vs. ERH).

Zhang et al. [35] prepararam nanoparticulas PtRuNi pelo método de microemulsão utilizando hidrazina como agente redutor. Foram preparadas nanoparticulas PtRuNi com direntes composiçōes atômicas (50:40:10, 80:10:10, 70:20:10, 65:30:05 e 60:35:05). Em todos os casos os difratogramas de raios $X$ apresentaram a estrutura CFC de $\mathrm{Pt}$ com valores $2 \theta$ deslocados para àngulos maiores, sendo que outras fases não foram observadas. $O$ deslocamento de $2 \theta$ corresponde à uma diminuição no parâmetro de rede devido à incorporação de átomos de $\mathrm{Ru}$ e $\mathrm{Ni}$ e indicam a formação de nanopartículas na forma de uma liga trimetálica. Os testes na eletrooxidação do 
metanol mostraram que adição de niquel aos eletrocatalisadores PtRu aumenta seu desempenho. Como também relatado por outros autores, o aumento de atividade foi atribuido às modificações das propriedades eletrônica da Pt pelo Ru e/ou Ni e também a formação de espécies oxigenadas a baixos potenciais.

Jeon et al.[36] prepararam o eletrocatalisador PtRuNi/C com razão atômica de 45:45:10 usando borohidreto como agente redutor. A difração de raios $X$ mostrou apenas a formação de uma fase CFC característica de Pt e suas ligas, não sendo observada a presença de outras fases. $\mathrm{Na}$ eletrooxidação de metanol a densidade de corrente a $0,5 \mathrm{~V}$ obtida para o catalisador PtRuNi/C foi de $2,9 \mathrm{~mA} . \mathrm{cm}^{-2}$ enquanto que para o catalisador comercial PtRu/C E-TEK foi de 2,6 mA. $\mathrm{cm}^{-2}$.

Lui et al. [37] preparam eletrocatalisadores a partir da incorporação de complexos carbonílicos no suporte de carbono e posterior redução em fluxo de $\mathrm{H}_{2}$ na faixa de temperatura entre 150 - $300^{\circ} \mathrm{C}$. Foram preparados eletrocatalisadores com razões atômicas Pt:Ru:Ni de 67,5:22,5:10, 60:30:10 e 50:40:10. Quando tratados entre $150^{\circ} \mathrm{C}$ e $300^{\circ} \mathrm{C}$ as análises por difração de raios $X$ mostraram um aumento do grau de liga com o aumento da temperatura. Os eletrocatalisadores PtRuNi/C preparados por esta metodologia apresentaram-se mais ativos que o catalisador comercial PtRu/C da JohnsonMatthey na eletrooxidação do metanol. A melhor atividade foi encontrada para o catalisador com razão atomica $60: 30: 10$ tratado a $175^{\circ} \mathrm{C}$. No entanto, a estabilidade, ao contrário da atividade, foi muito maior para eletrocatalisadores tratados a temperaturas maiores que $250^{\circ} \mathrm{C}$. Os autores atribuíram o aumento na estabilidade ao aumento no grau de liga das nanoparticulas PtRuNi. Por outro lado, foi constatado que a queda de atividade para eletrocatalisadores PtRuNi/C tratados em temperatura menores que $200{ }^{\circ} \mathrm{C}$ não foi devido à dissolução do $\mathrm{Ni}$. 


\section{OBJETIVOS}

Diversos estudos têm mostrado que os eletrocatalisadores PtRuNi/C preparados por diferentes metodologias mostraram-se mais ativos na eletrooxidação de metanol que os eletrocatalisadores PtRu/C. Os eletrocatalisadores PtRu/C preparados pelo método da redução por álcool desenvolvido no IPEN/CNEN-SP mostraram-se bastante ativos na eletrooxidação de álcoois. No entanto, como os álcoois são agentes redutores moderados a fracos, e os ions $\mathrm{Ni}^{+2}$ não nnssuem um potencial de redução tão favorável como os ions de metais nobres, $\mathrm{Pt}^{+4}$ e $\mathrm{Ru}^{+3}$; o objetivo deste trabalho é estudar a viabilidade de preparação de eletrocatalisadores PtRuNi/C pelo método da redução por álcool e testa-los na eletrooxidação de metanol visando aplicação como ânodo em células a combustivel tipo DMFC. 


\section{PROCEDIMENTOS EXPERIMENTAIS}

\subsection{Preparação e Caracterização dos Eletrocatalisadores PtRuNi/C}

Os eletrocatalisadores PtRu/C e PtRuNi/C foram preparados pelo método da redução por álcool [21, 22]. Foram utilizados $\mathrm{H}_{2} \mathrm{PtCl}_{6} \cdot 6 \mathrm{H}_{2} \mathrm{O}$ (Aldrich), $\mathrm{RuCl}_{3} .1,5 \mathrm{H}_{2} \mathrm{O}$ (Aldrich) e $\mathrm{NiCl}_{2} \cdot 6 \mathrm{H}_{2} \mathrm{O}$ (Aldrich) como fonte de metais, etileno glicol (Merck) como solvente e agente redutor e Carbon Vulcan XC72R como suporte. Os sais metálicos foram dissolvidos em uma mistura de etileno glicol/água de $3: 1(\mathrm{v} / \mathrm{v})$ e o suporte de carbono foi adicionado a esta solução. A mistura resultante foi tratada em banho de ultra-som por 5 min e após isso foi submetida a refluxo por $3 \mathrm{~h}$. Após, o sólido foi filtrado, lavado com água e seco a $70^{\circ} \mathrm{C}$ por $2 \mathrm{~h}$ como mostrado na FIG. 3. Os zletrocatalisadores PiRu/C (razão atômica Pt:Ru de 50:50) e PtRuNi/C (razões atômicas Pt:Ru:Ni de: 70:20:10, $60: 30: 10,50: 40: 10,50: 25: 25,40: 30: 30$ e 50:10:40) foram preparados com $20 \%$ de metais em massa. Algumas sínteses foram realizadas variando $0 \mathrm{pH}$ do meio reacional e, neste caso, a razão molar $\mathrm{OH}^{-} /$metais foi variada entre 4 e 12 . Para isto uma solução $\mathrm{KOH} 1 \mathrm{~mol}$. $\mathrm{L}^{-1}$ foi utilizada.

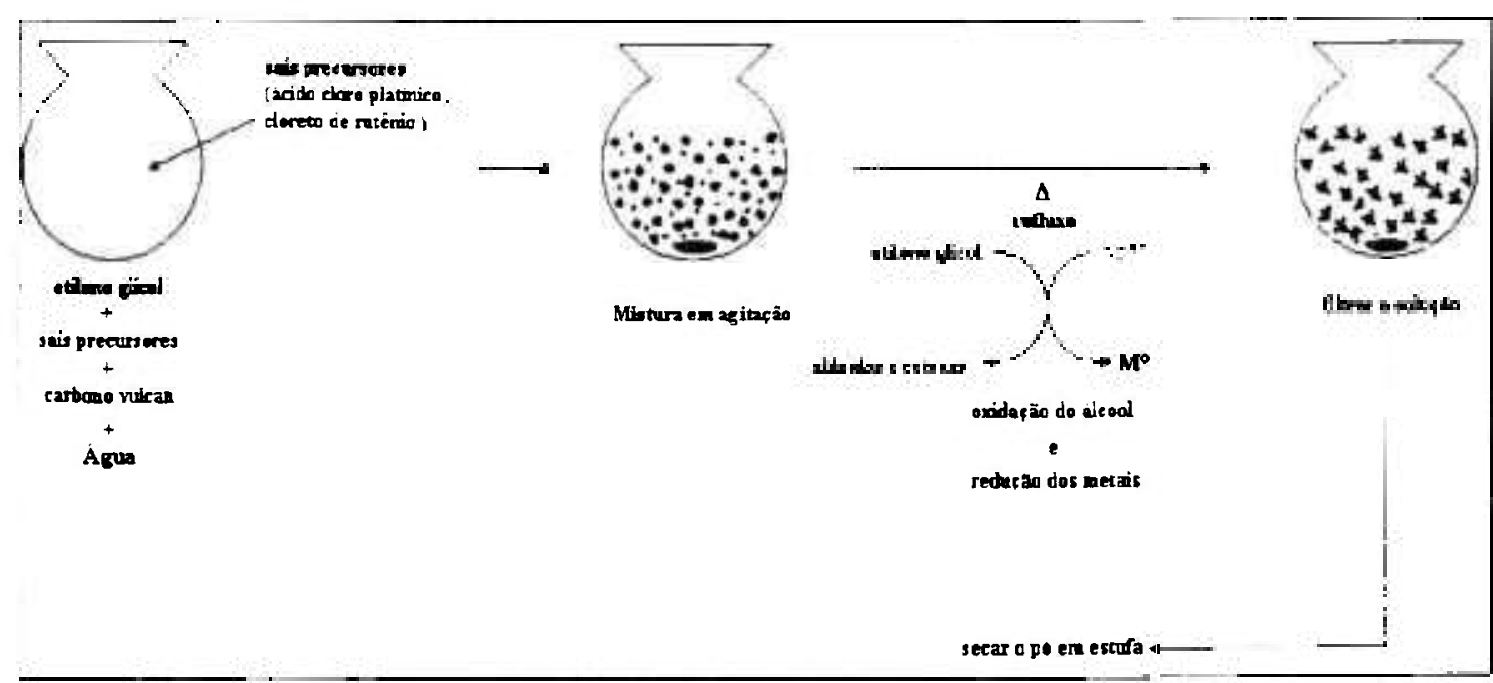

FIGURA 3 - Esquema do processo de sintese dos eletrocatalisadores. 
A identificação qualitativa dos ions $\mathrm{Ni}(I I)$ no meio reacional foi efetuada através da formação de um complexo com a dimetilglioxima [38] após a separação do catalisador por filtração.

\subsection{Caracterização físico-química dos eletrocatalisadores PtRuNi/C}

As razões atômicas PtRu e Pt:Ru:Ni foram determinadas por análise de raios $X$ por energia dispersiva (EDX) usando um microscópio eletrônico de varredura Phillips XL30 com um feixe de elétrons de $20 \mathrm{KeV}$ e equipado com um microanalisador EDAX DX-4.

As análises por difração de raios $X(X R D)$ foram realizadas em um difratômetro Rigaku modelo Multiflex usando uma fonte radiação CuKa. $O$ tamanho médio de cristalito foi estimado utilizando-se a equação de Scherrer Eq. 20 [39].

$$
d=\frac{\mathrm{K} \cdot \lambda}{\beta \cdot \cos \theta}
$$

Onde $d$ é o diâmetro médio dos cristalitos em Angstrons, $K$ é uma constante que depende da forma dos cristalitos, foi utilizado o valor de $K=0,9$ admitindo-se cristalitos esféricos; $\lambda$ é o comprimento de onda da radiação usada, no caso do $\mathrm{Cu} \Lambda=1,54056 \AA ; \beta$ é a largura a meia altura do pico em radianos e $\theta$ é $\circ$ ângulo de Bragg em graus para o ponto máximo do pico analisado, e o pico utilizado para estimar o tamanho médio de cristalito foi o $2 \theta=67^{\circ}[39]$.

As análises termogravimétricas (TGA) foram realizadas em um equipamento Shimadzu D-50. As amostras foram aquecidas em um cadinho de platina, da temperatura ambiente até $1000^{\circ} \mathrm{C}$, com uma taxa de aquecimento igual a $5{ }^{\circ} \mathrm{C} \cdot \mathrm{min}^{-1} \mathrm{em}$ atmosfera de oxigênio seco $(30 \mathrm{~mL} / \mathrm{min})$. A análise termogravimétrica possibilita verificar a carga metálica presente no catalisador [40]. Este dado é necessário para o cálculo da porcentagem de Pt contida no catalisador para, futuramente, ser utilizada na normalização dos resultados eletroquimicos (I/Ampere por grama de $\mathrm{Pt}$ ). 
As análises por microscopia eletrônica de transmissão (TEM) foram realizadas em um microscópio eletrônico JEOL JEM 2100 operando a $200 \mathrm{kV}$. As amostras de eletrocatalisadores foram dispersas em álcool isopropilico em banho de ultrasom e gotas desta suspensão foram depositadas em um suporte de cobre com collodion $2 \%$ recoberto com carbono.

\subsection{Eletro-oxidação de metanol}

A eletro-oxidação de metanol foi estudada por voltametria cíclica e cronoamperometria usando a técnica de eletrodo de camada fina porosa [41]. O eletrodo de camada fina porosa foi preparado pela adição de $20 \mathrm{mg}$ do catalisador e 3 gotas de solução de Teflon em $50 \mathrm{~mL}$ de água. A mistura resultante foi colocada em um sistema de ultra-som por $10 \mathrm{~min}$ sob agitação. Após este período a mistura foi tiltrada em um filtro Millipore HAWP04700. A mistura ainda úmida foi então retirada do filtro com auxílio de uma espátula $e$ colocada sobre a cavidade do eletrodo $\left(0,30 \mathrm{~mm}\right.$ de profundidade e $0,28 \mathrm{~cm}^{2}$ de área), sob leve pressão, procurando deixar a superficie o mais homogênea possivel. A quantidade de eletrocatalisador no eletrodo de trabalho foi determinada com precisão de 0,0001 g. Na FIG. 4 mostra um esquema simplificado do eletrodo de camada fina porosa.

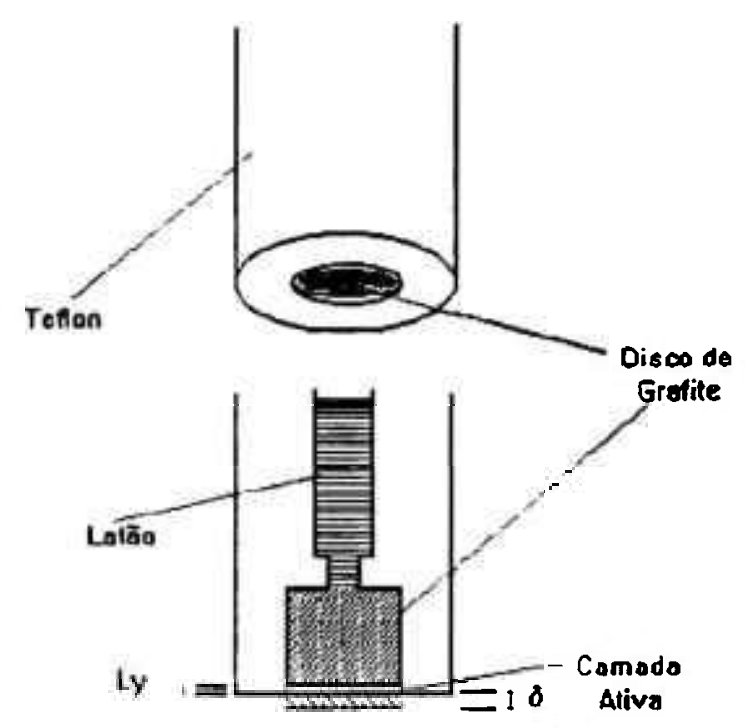

FIGURA 4 - Diagrama esquemático do eletrodo de camada fina porosa. 
As medidas eletroquimicas foram realizadas em um potenciostato/galvanostato Microquimica modelo MQP01 acoplado a um computador. Os perfis voltamétricos dos diferentes eletrocatalisadores foram obtidos em uma célula eletroquímica de um compartimento, contendo um eletrodo de referência de hidrogênio e um contra-eletrodo de platina platinizado. Os experimentos foram realizados em soluçāo de $\mathrm{H}_{2} \mathrm{SO}_{4} 0,5$ mol L' ${ }^{1}$ com uma velocidade de varredura de $10 \mathrm{mV} \mathrm{s}^{-1}$. Na FIG. 5 pode-se observar um esquema simplificado desta célula com seus principais componentes.

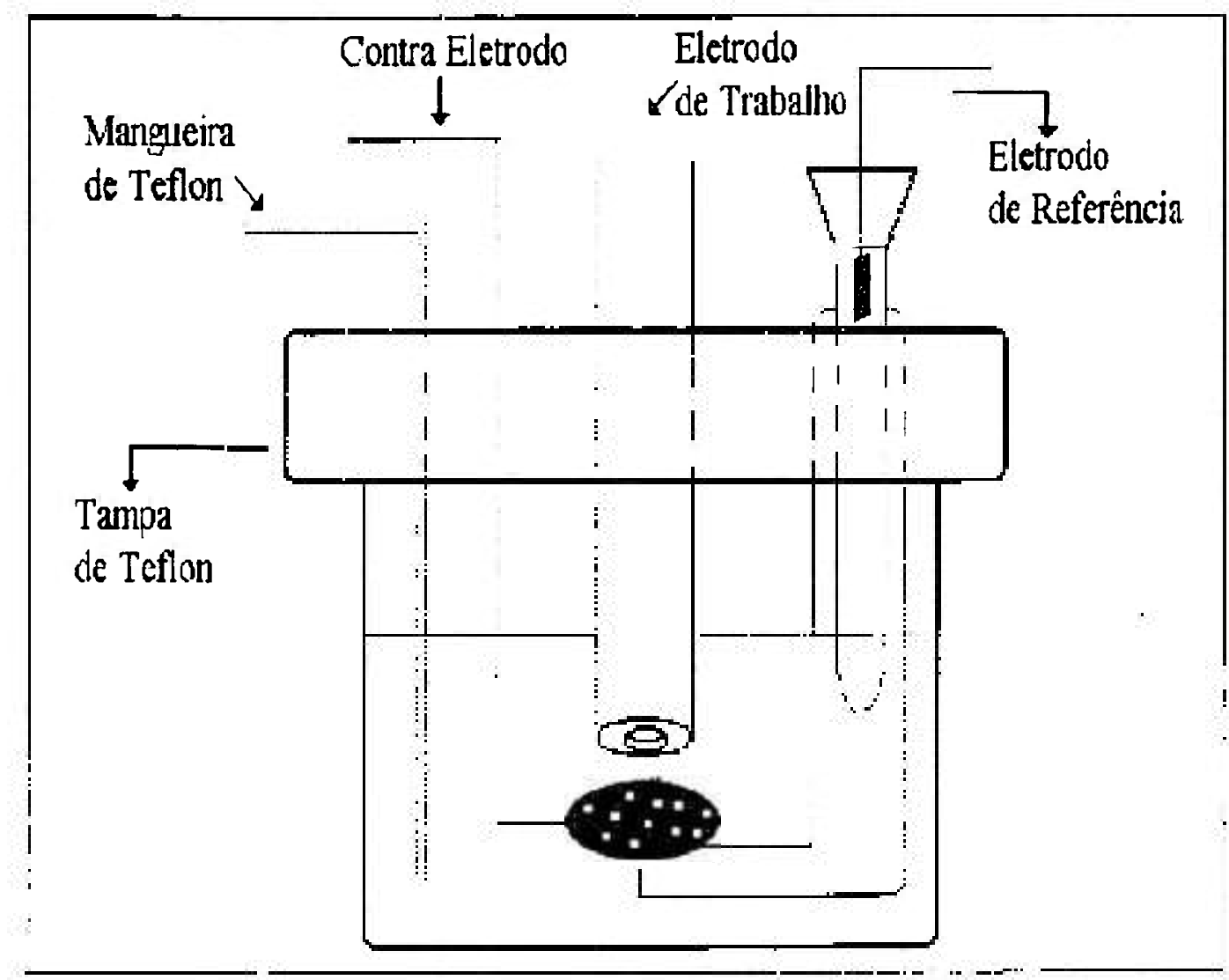

FIGURA 5 - Representação esquemática da célula eletroquímica usada para realizaçāo das medidas de voltametria e cronoamperometria e por eletrodo de camada fina porosa.

Os estudos da eletro-oxidação de metanol foram realizados a temperatura ambiente utilizando soluçāo $1,0 \mathrm{~mol} \mathrm{~L}^{-1}$ de metanol em $0,5 \mathrm{~mol} \mathrm{~L}^{-1}$ de $\mathrm{H}_{2} \mathrm{SO}_{4}$. Nestes experimentos os valores de corrente (I) são expressos em Amperes e normalizados por grama de platina $\left(\mathrm{A} \mathrm{gPt}^{-1}\right)$. A quantidade de platina 
é calculada considerando a massa de eletrocatalisador presente no eletrodo de trabalho multiplicada por sua porcentagem de platina (considerando os valores obtidos por análise termogravimétrica e as análises por EDX). Os estudos de cronoamperometria foram realizados em solução $1,0 \mathrm{~mol} \mathrm{~L}^{-1}$ de metanol em 0,5 mol L ${ }^{-1}$ de $\mathrm{H}_{2} \mathrm{SO}_{4}$. O eletrocatalisador comercial PtRu/C E-TEK (20\% massa, razão atômica Pt: Ru de 50:50, (Lote B0011117) foi utilizado para comparação por ser considerado como referência em termos de desempenho na oxidação de misturas $\mathrm{H}_{2} / \mathrm{CO}$ e na oxidação direta de metanol [42]. 


\section{RESULTADOS E DISCUSSÕES}

\subsection{Preparação dos eletrocatalisadores PtRuNi/C pelo método da redução por álcool}

Inicialmente os eletrocatalisadores PtRu/C (razão atômica Pt:Ru de 50:50) e PtRuNi/C (razão atômica Pt:Ru:Ni de 50:40:10 e 50:10:40) foram preparados pela co-redução dos ions $\mathrm{Pt}(\mathrm{IV}), \mathrm{Ru}(\mathrm{III})$ e Ni (II) usando etileno glicol como solvente e agente redutor na presença do suporte de carbono TAB 1. Os meios reacionais da preparação destes eletrocatalisadores apresentaram um valor de $\mathrm{pH}$ de cerca de 3.

TABELA 1 - Razão atômica e tamanho médio de cristalito dos eletrocatalisadores PtRu/C e PtRuNi/C preparados pelo método da redução por álcool.

\begin{tabular}{ccccc}
\hline catalisador & $\begin{array}{c}\text { Pt:Ru:Ni } \\
\text { nominal } \\
\text { (razão } \\
\text { atômica) }\end{array}$ & $\begin{array}{c}\text { Pt:Ru:Ni EDX } \\
\text { (razão atômica) }\end{array}$ & $\begin{array}{c}\text { Tamanho médio } \\
\text { de cristalito } \\
\text { (nm) }\end{array}$ & $\begin{array}{c}\text { Massa de } \\
\text { metais TGA } \\
(\%)\end{array}$ \\
\hline PtRu/C & $50: 50$ & $49: 51$ & 2,7 & 20 \\
PtRu/C E-TEK & $50: 50$ & $46: 54$ & $<2,0$ & 24 \\
& & & & 18 \\
PtRuNi/C & $50: 10: 40$ & $80: 17: 03$ & 2,2 & 20 \\
\hline
\end{tabular}

Para o eletrocatalisador PtRu/C preparados pelo método da redução por álcool e o eletrocatalisador comercial PtRu/C E-TEK as análises por EDX mostraram que as razões atômicas $\mathrm{Pt}$ Ru são bastante similares as razões nomimais (50:50) como mostrado na TAB. 1. 
Nos espectros de energia dispersiva de raios $X$ (EDX) para os eletrocatalisadores PtRu/C E-TEK e PtRu/C preparados pelo método de redução por álcool FIG. 6, podemos observar os picos relativos a platina e ao rutênio.

PtRu/C (50:50) E-TEK $c$
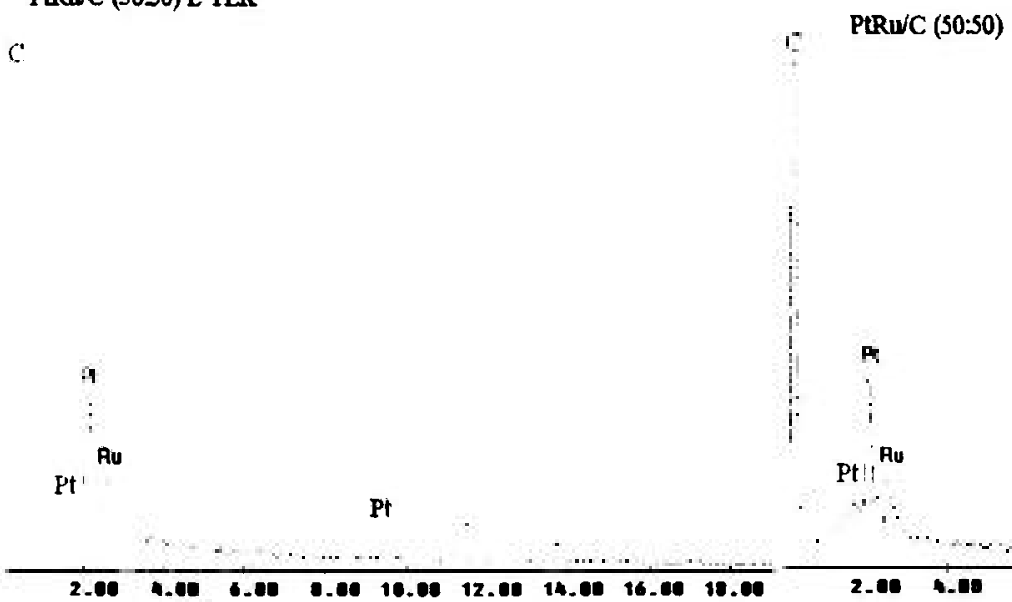

Pt $11^{\text {Au }}$

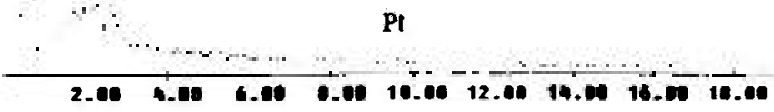

FIGURA 6 - Espectros dos eletrocatalisadores PtRu/C (50:50) E-TEK e PtRu/C (50:50) preparados pelo método de redução por álcool.

A análise termogravimétrica FIG. 7 do eletrocatalisador PtRu/C (50:50) preparado pelo método da redução por álcool mostra o conteúdo total de metais que foi depositado no suporte de carbono (20\% em massa) ao passo que o eletrocatalisador comercial PtRu/C E-TEK apresenta um valor de $24 \%$ (o valor declarado pelo fabricante é de $20 \%$ ). 


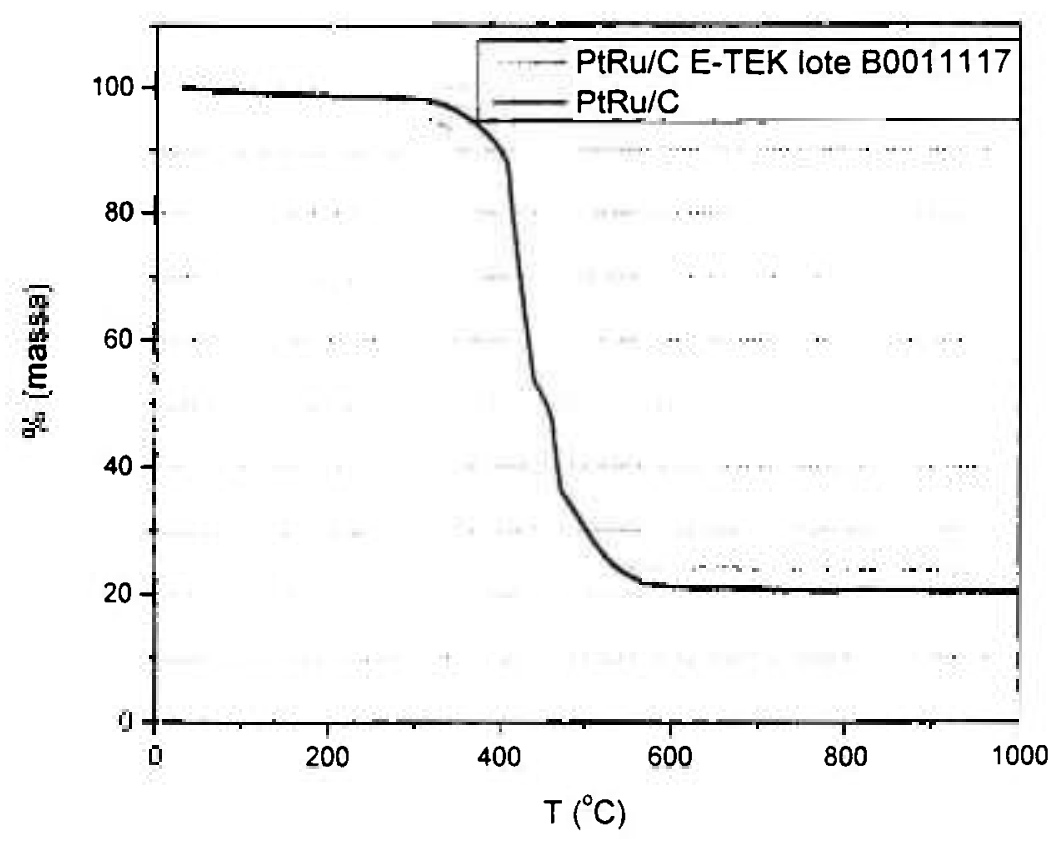

FIGURA 7 - Análises Termogravimetricas PtRu/C, temperatura ambiente até $1000^{\circ} \mathrm{C}$, com uma taxa de aquecimento igual a $5^{\circ} \mathrm{C} \cdot \mathrm{min}^{-1} \mathrm{em}$ atmosfera de oxigênio seco (30 mL. $\left.\mathrm{min}^{-1}\right)$.

Para os eletrocatalisadores PtRuNi/C TAB. 1 as razões atômicas apresentaram-se muito diferentes das razōes atômicas nominais, ou seja, 80:17:03 e 53:44:03 para os eletrocatalisadores preparados com razões nominais 50:10:40 e 50:40:10, respectivamente. Isto, a principio, sugere que os ions $\mathrm{Ni}$ (II) não foram reduzidos e/ou incorporados no suporte de carbono. $\mathrm{O}$ teste qualitativo com dimetilglioxima realizadas nos meios reacionais após a separação dos eletrocatalisadores confirmou a presença de ions $\mathrm{Ni}(\mathrm{II})$ nestes meios [38].

Os difratogramas dos eletrocatalisadores preparados pelo método de redução por álcool são mostrados na FIG. 8. Observa-se em todos os difratogramas um pico largo em aproximadamente $2 \theta=25^{\circ}$, o qual é associado ao suporte de carbono Vulcan XC72R. Os eletrocatalisadores PtRu/C e PtRuNi/C, apresentam três picos de difração em aproximadamente $2 \theta=40^{\circ}$, $47^{\circ}$ e $67^{\circ}$, os quais são associados aos planos (111), (200) e (220), respectivamente, da estrutura cúbica de face centrada (CFC) de platina e ligas 
de platina [39]. Nestes difratogramas picos relativos as fases CFC de $\mathrm{Ni}$ metálico, hexagonal compacto (HCP) de $\mathrm{Ru}$ metálico ou de fases óxidos/hidróxidos de Ru ou Ni não são evidentes.

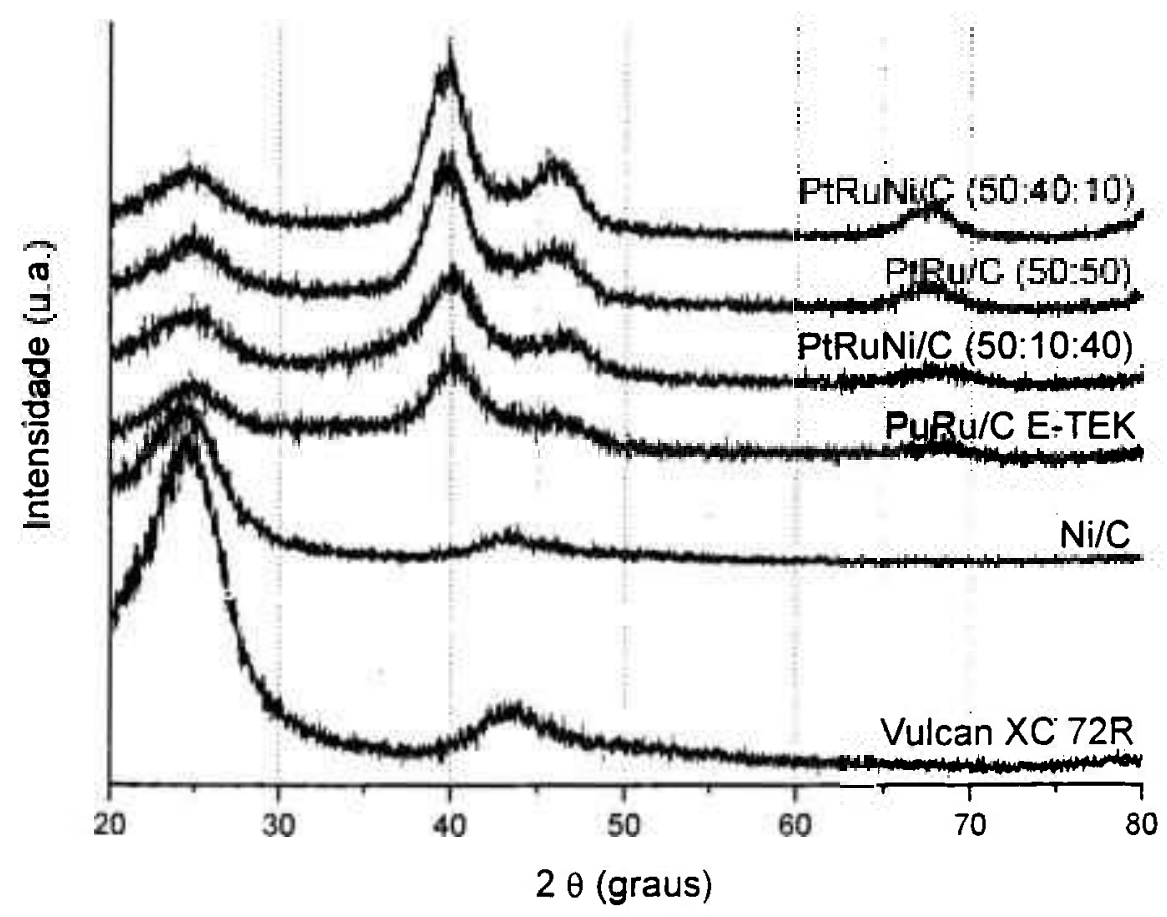

FIGURA 8 - Difratogramas de raios $X$ dos eletrocatalisadores PtRu/C e PtRuNi/C.

O difratograma de raios $\mathrm{X}$ do catalisador Ni/C obtido apresenta-se similar ao do suporte de carbono Vulcan $X C 72 R$, sugerindo que os ions $\mathrm{Ni}$ (II) não foram reduzidos e depositados no suporte de carbono, como observado na análise de EDX e também na detecção de ions Ni (II) no meio reacional.

$\mathrm{Na}$ FIG. 9 são mostrados os voltamogramas cíclicos dos eletrocatalisadores em solução $0,5 \mathrm{~mol} \cdot \mathrm{L}^{-1}$ de $\mathrm{H}_{2} \mathrm{SO}_{4}$. Observa-se para todos eletrocatalisadores a região de adsorção-desorção de hidrogênio $(0,0-0,4 \mathrm{~V})$ pouco definida o que é característico de ligas de PtRu [43]. Para o eletrocatalisador PtRuNi/C de razão nominal 50:10:40, observa-se a região de dupla-camada $(0,4-0,8 \mathrm{~V})$ mais estreita, a qual é caracteristica de eletrocatalisadores PtRu com maiores quantidades de Platina [43]. Na 
realidade a análise de EDX mostrou que este eletrocatalisador apresentou uma razão Pt:Ru:Ni de aproximadamente 80:17:03.

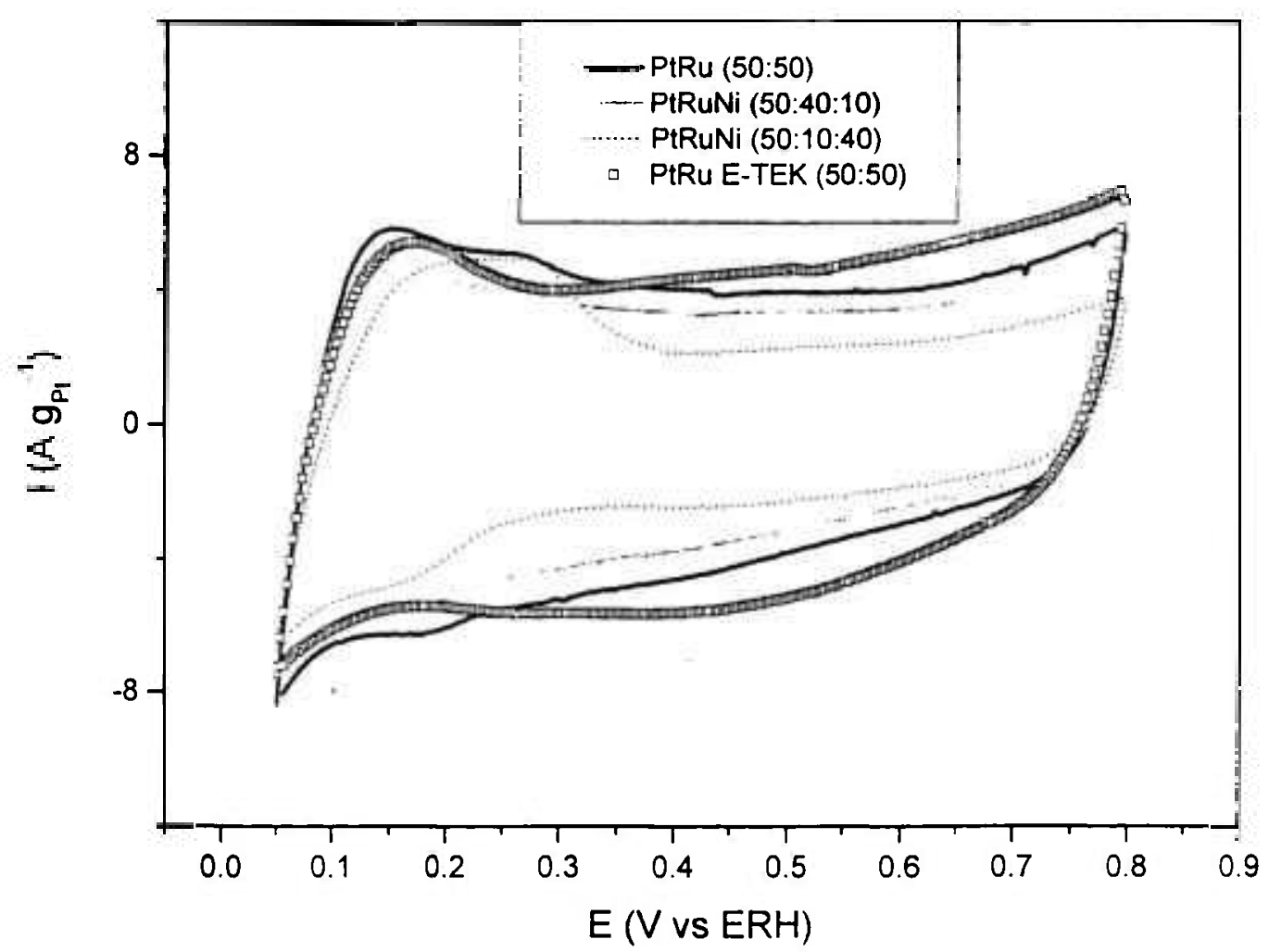

FIGURA 9 - Voltamogramas cíclicos obtidos em solução $0.5 \mathrm{~mol}^{-1} \mathrm{~L}^{-1}$ de $\mathrm{H}_{2} \mathrm{SO}_{4}$ para os eletrocatalisadores PtRu/C E-TEK, PtRu/C e PtRuNi/C preparados pelo método da redução por álcool.

$\mathrm{Na}$ FIG. 10 são mostrados os voltamogramas lineares para os eletrocatalisadores PtRu/C E-TEK, PtRu/C e PtRuNi/C em solução $0,5 \mathrm{~mol} \mathrm{~L}^{-1}$ de $\mathrm{H}_{2} \mathrm{SO}_{4}$ e 1,0 mol. $\mathrm{L}^{-1}$ de metanol a uma velocidade de varredura de $10 \mathrm{mVs}^{-1}$. Nota-se que todos eletrocatalisadores começam a eletro-oxidação do metanol a aproximadamente $0,3 \mathrm{~V}$, porem os eletrocatalisadores Pt:Ru: $\mathrm{Ni}(50: 40: 10)$ e PtRu (50:50) apresentaram maiores valores de corrente em relação ao eletrocatalisador PtRuNi (50:10:40) e PtRu/C E-TEK. 


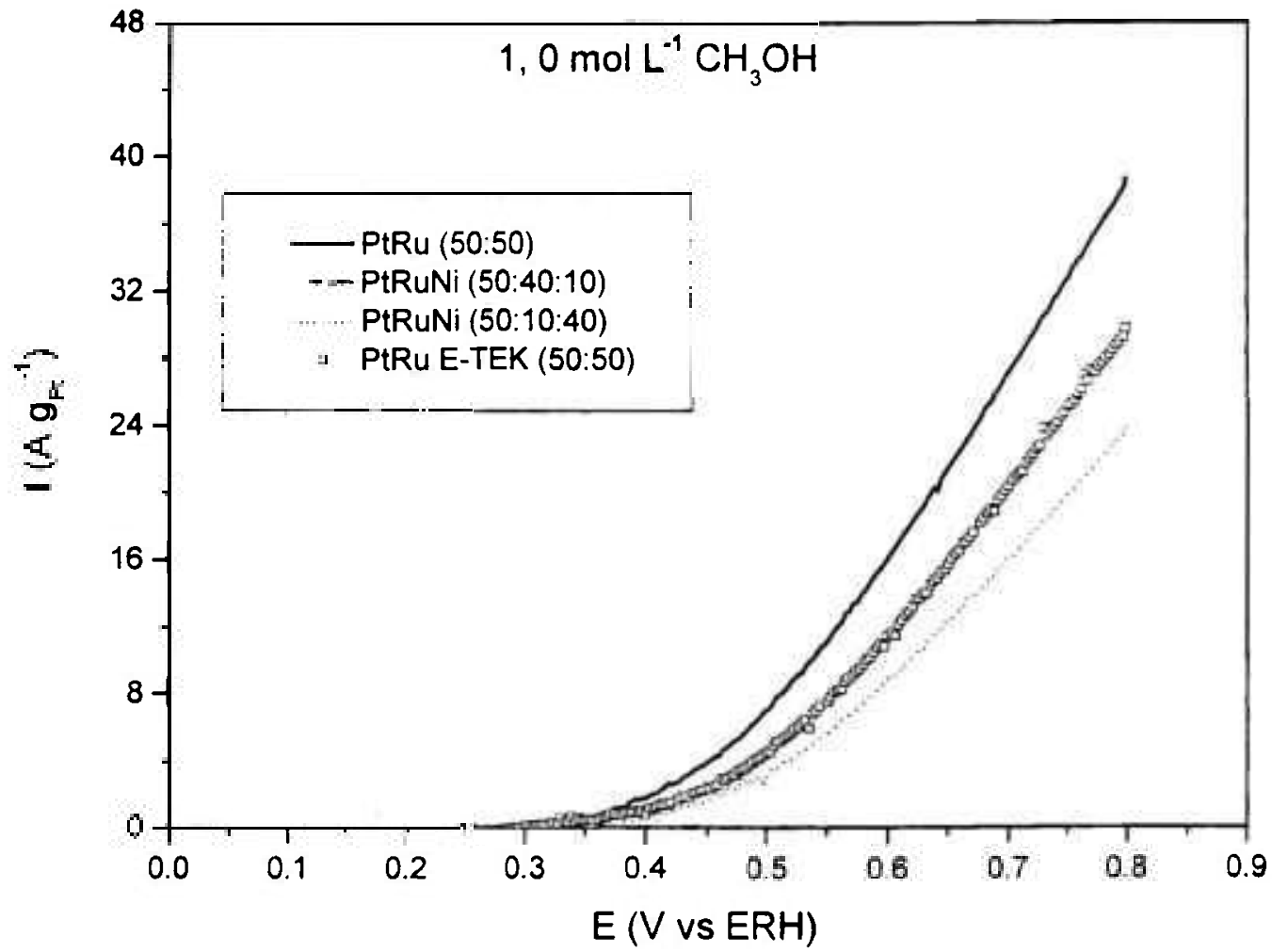

FIGURA 10 - Comparação dos valores de corrente para PtRu/C e PtRuNi/C preparados pelo método da redução por álcool na presença de $1,0 \mathrm{~mol} \cdot \mathrm{L}^{-1}$ de metanol, considerando-se apenas a varredura anódica, sendo esta corrigida pelo voltamograma base.

Na FIG 11 são apresentados os estudos de cronoamperometria em 500 $\mathrm{mV}$ por $30 \mathrm{~min}$. O sistema PtRu/C preparado pelo método de redução por álcool apresentou um desempenho um pouco inferior ao eletrocatalisador PtRu/C E-TEK enquanto que o eletrocatalisadores PtRuNi/C apresentaram desempenhos bastantes inferiores; no entanto, cabe ressaltar que nas condições de preparação utilizadas os íons $\mathrm{Ni}$ (II) não foram reduzidos nem incorporados nestes eletrocatalisadores. Isto provavelmente é devido ao alto potencial de redução dos ions Ni (II) comparado aos ions de metais nobres Pt e Ru Eq 20-25.

$\left[\mathrm{PtCl}_{6}\right]^{2-}+2 \mathrm{e}^{\circ} \rightarrow \quad\left[\mathrm{PtCl}_{4}\right]^{2-}+2 \mathrm{Cl}^{\circ} \quad \mathrm{E}^{\circ}=0,68 \mathrm{~V} \quad$ Equação 20 


$\begin{array}{lll}{\left[\mathrm{PtCl}_{4}\right]^{2-}+2 \mathrm{e}^{-} \leftrightarrow \mathrm{Pt}+4 \mathrm{Cl}^{-}} & \mathrm{E}^{\circ}=0,755 \mathrm{~V} & \text { Equação 21 } \\ \mathrm{Ru}^{3+}+\mathrm{e}^{-} \leftrightarrow \mathrm{Ru}^{2+} & \mathrm{E}^{\circ}=0,2487 \mathrm{~V} & \text { Equação 22 } \\ \mathrm{Ru}^{2+}+2 \mathrm{e}^{-} \rightarrow \mathrm{Ru} & \mathrm{E}^{\circ}=0,455 \mathrm{~V} & \text { Equação 23 } \\ \mathrm{CH}_{3} \mathrm{CH}_{2} \mathrm{OH} \leftrightarrow \mathrm{CH}_{3} \mathrm{CHO}+2 \mathrm{H}^{+}+\mathrm{e}^{-} & \mathrm{E}^{\circ}=-0,16 \mathrm{~V} & \text { Equação 24 } \\ \mathrm{Ni}^{2+}+2 \mathrm{e}^{-} \leftrightarrow \mathrm{Ni} & \mathrm{E}^{\circ}=-0,257 \mathrm{~V} & \text { Equação 25 }\end{array}$

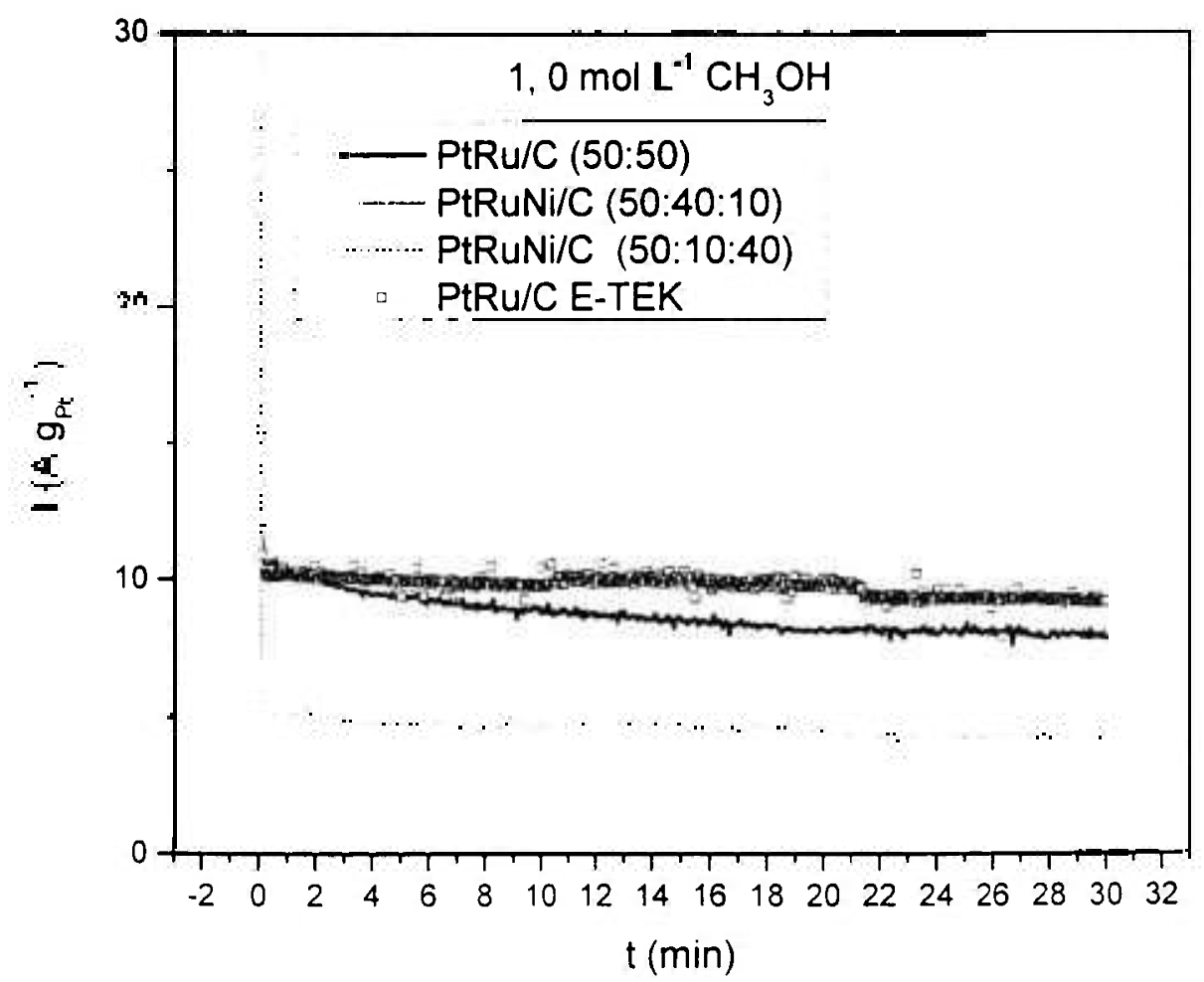

FIGURA 11 - Comparaçāo das curvas cronoamperométricas para os eletrocatalisadores PtRu/C e PtRuNi/C com potencial fixo de $500 \mathrm{mV}$ por 30 $\min$.

4.2 Preparação dos eletrocatalisadores PtRuNi/C pelo metodo de redução por álcool de redução por álcool em meio alcalino.

Dessa forma, modificações foram realizadas no procedimento de preparação, a fim de incorporar Ni nestes materiais. As sinteses foram então realizadas em meio básico, mediante a adição de uma solução de $\mathrm{KOH}$ ao 
meio reacional (razão molar $\mathrm{OH}^{-} /$metais $=8$ ). $\mathrm{O} \mathrm{pH}$ do meio reacional foi mantido na faixa de 11-12, o que permite, a princípio, depositar os ions $\mathrm{Ni}(\mathrm{II})$ na forma de óxido ou hidróxido, ao passo que, os íons Pt(IV) e Ru(III) continuam a ser reduzidos pelo etileno glicol à forma metálica nestas condições [44]. Os eletrocatalisadores PtRu/C e PtRuNi/C com razões atômicas 50:50 e 50:40:10, respectivamente, preparados em meio alcalino são mostrados na TAB. 2. As razões atômicas obtidas por EDX para os eletrocatalisadores PtRu/C e PtRuNi/C preparados na presença de $\mathrm{KOH}$ são bastante próximas às razões nominais.

TABELA 2 - Razão atômica e tamanho médio de cristalitos dos eletrocatalisadores $\mathrm{PtRu} / \mathrm{C}$ e PtRuNi/C preparados pelo método da redução por álcool utilizando uma razão molar $\mathrm{OH}^{-} /$metais $=8$.

\begin{tabular}{ccccc}
\hline catalisador & $\begin{array}{c}\text { Pt:Ru:Ni } \\
\text { nominal } \\
\text { (razão } \\
\text { atômica) }\end{array}$ & $\begin{array}{c}\text { Pt:Ru:X EDX } \\
\text { (razão } \\
\text { atômica) }\end{array}$ & $\begin{array}{c}\text { Tamanho } \\
\text { médio de } \\
\text { cristalito }(\mathrm{nm})\end{array}$ & $\begin{array}{c}\text { Massa de } \\
\text { metais TGA } \\
(\%)\end{array}$ \\
\hline PtRu/C & $50: 50$ & $54: 46$ & $<2,0$ & 8 \\
PtRuNi/C & $50: 40: 10$ & $49: 35: 16$ & $<2,0$ & 10 \\
\hline
\end{tabular}

O espectro de EDX do eletrocatalisador PtRuNi 50:10:40 é mostrado na FIG. 12. Neste caso, pode-se observar o pico referente ao Niquel. Os tamanhos médio de cristalito para os materiais preparados em meio ácido foram maiores que $2 \mathrm{~nm}$ TAB. 1, enquanto que, para os eletrocatalisadores preparados em meio alcalino foram menores que $2 \mathrm{~nm}$ TAB. 2. O menor tamanho médio de cristalito pode ser atribuído à estabilização eletrostática dos ions $\mathrm{OH}^{-}$adsorvidos nas superfícies das nanopartículas metálicas inibindo seu crescimento e aglomeração [44]. 
PtRuNic (50:40:10) com KOH

C

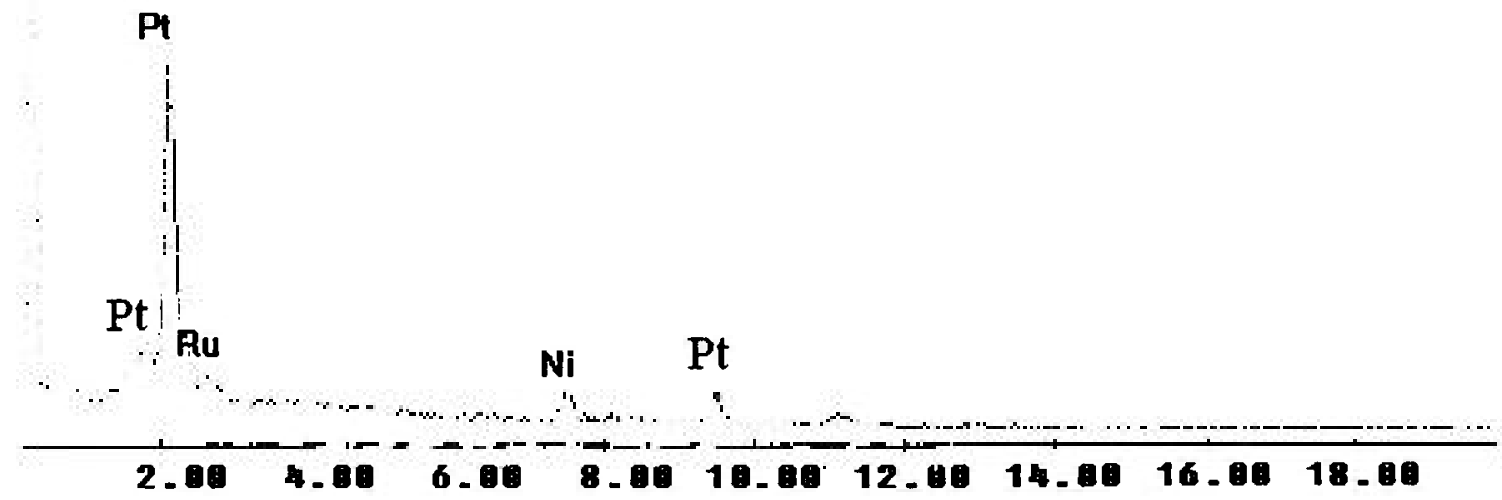

FIGURA 12 - Espectro do eletrocatalisador PtRuNi/C (50:40:10) preparado pelo método de redução por álcool utilizando uma razão molar $\mathrm{OH}^{-} / \mathrm{Me}=8$.

As análises termogravimétricas apresentadas na FIG. 13 das arnostras preparadas em meio alcalino indicam que apenas cerca de $10 \%$ dos metais foram depositados no suporte de carbono. Como as análises de EDX TAB. 2 indicaram que às razões Pt:Ru obtidas são próximas as razões nominais, sugere-se que o metais foram reduzidos, porém, nem todas as nanopartículas formadas foram depositadas no suporte de carbono. É descrito na literatura a preparação de nanopartículas de $\mathrm{Pt}$ em solução estabilizadas por ions $\mathrm{OH}^{-}$ utilizando etileno glicol como solvente e agente redutor [44]. 


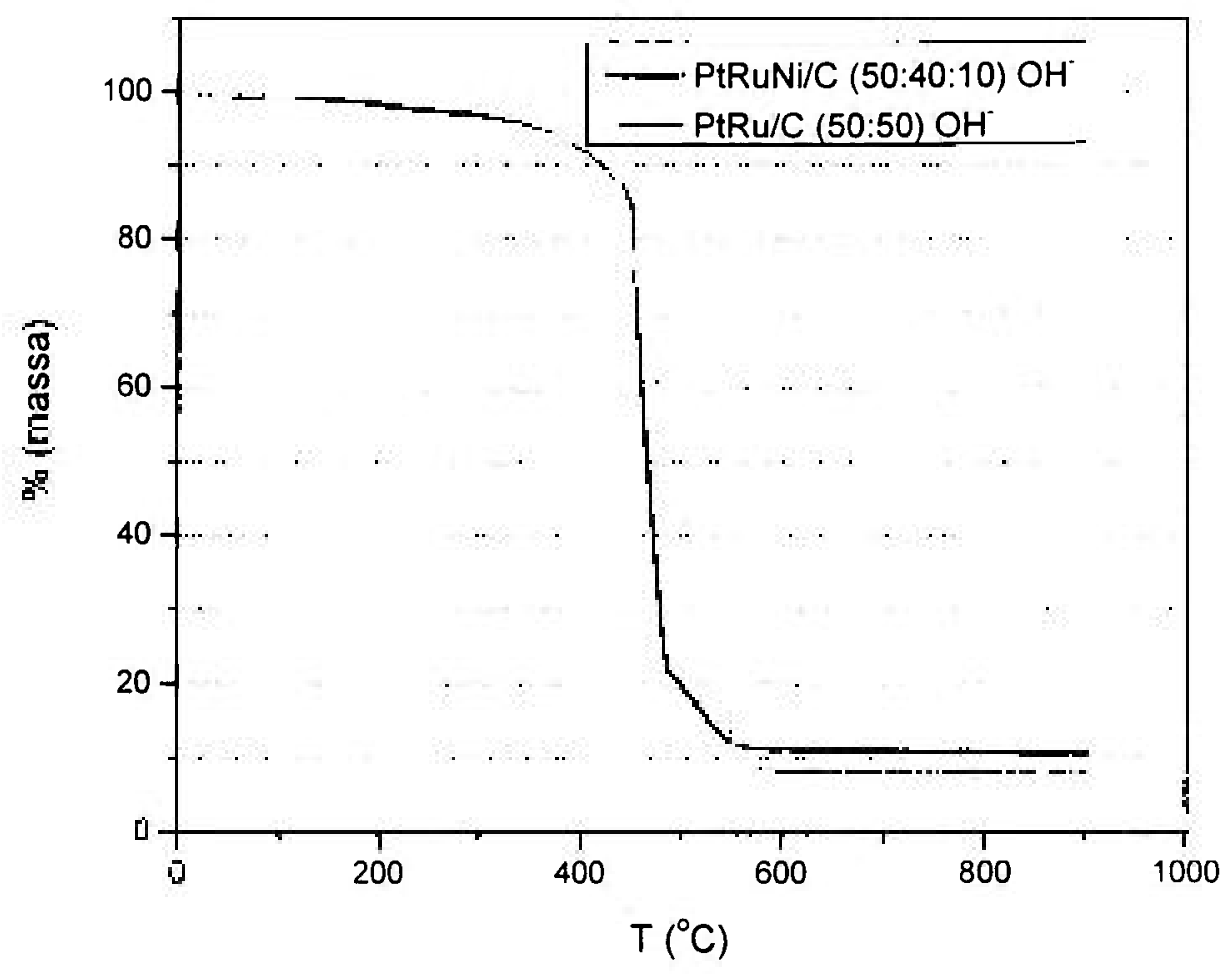

FIGURA 13 - Análises Termogravimetricas PtRu/C e PtRuNi/C preparadas em meio alcalino, temperatura ambiente até $900^{\circ} \mathrm{C}$, com uma taxa de aquecimento igual a $5^{\circ} \mathrm{C} \cdot \mathrm{min}^{-1} \mathrm{em}$ atmosfera de oxigênio seco $\left(30 \mathrm{~mL} \cdot \mathrm{min}^{-1}\right)$.

$\mathrm{Na}$ FIG. 14 são mostrados os difratogramas dos eletrocatalisadores preparados em meio alcalino. O difratograma do eletrocatalisador $\mathrm{Ni} / \mathrm{C}$ apresenta picos em $2 \theta=33,47$ e $60^{\circ}$, os quais correspondem a uma fase metálica Ni tetragonal [45]. Esta fase foi também identificada na preparação de nanoparticulas de $\mathrm{Ni}$, onde o $\mathrm{NiCl}_{2} \cdot 6 \mathrm{H}_{2} \mathrm{O}$ foi reduzido com $\mathrm{NaBH}_{4}$ em meio aquoso à temperatura ambiente [45]. Os autores propõem que a fase metálica $\mathrm{Ni}$ tetragonal formada nestas condições é estabilizada por átomos de oxigênio "dissolvidos" na rede de Ni. O difratograma do eletrocatalisador PtRuNi/C com razão atômica Pt:Ru:Ni de 50:40:10 apresenta os picos característicos da estrutura cúbica de face centrada (CFC) de Pt e suas ligas $(2 \theta=40,47$ e 67). Não são evidentes, nestes difratogramas, os picos relativos à fase $\mathrm{Ni}$ tetragonal, bem como, os picos relativos a fases óxidos/hidróxidos de Ru ou Ni. No entanto, observa-se no difratograma do eletrocatalisador PtRuNi/C um deslocamento do picos relativos a fase CFC de Pt e suas ligas para ângulos 
maiores quando comparado aos eletrocatalisdores $P t R u / C$, o que pode ser atribuido a incorporação de $\mathrm{Ni}$ na estrutura CFC da Pt. Hedge et al. [46] observaram que nanopartículas de Ni com estrutura CFC podem ser formadas a partir de $\mathrm{Ni}(\mathrm{OH})_{2}$ em etiler.o glicol usando $\mathrm{Pd}$ ou $\mathrm{Pt}$ como agentes nucleantes. Como estas condições são bastante similares às utilizadas em nossa metodologia, o deslocamento dos picos da fase CFC para ângulos maiores sugere que os ions $\mathrm{Ni}(\mathrm{II})$ foram reduzidos e incorporados na fase CFC de Pt e suas ligas.

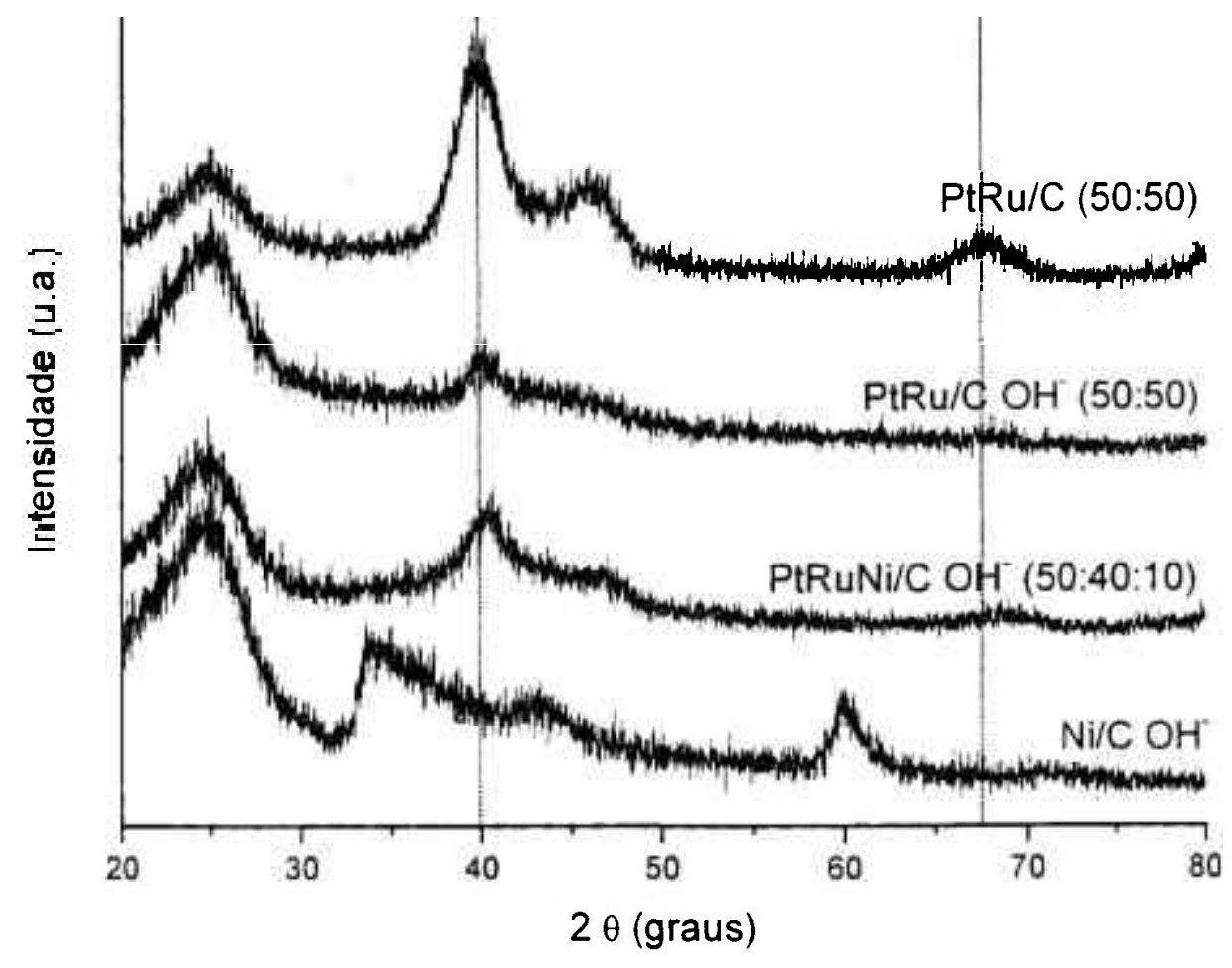

FIGURA 14 - Difratogramas de raios $X$ dos eletrocatalisadores PtRu/C e $\mathrm{PtRuNi} / \mathrm{C}$

$\mathrm{Na}$ FIG. 15 são apresentados os voltamogramas ciclicos dos eletrocatalisadores em solução 0,5 mol. $\mathrm{L}^{-1}$ de $\mathrm{H}_{2} \mathrm{SO}_{4}$. Observa-se para todos os eletrocatalisadores a região de adsorção-dersoção de hidrogênio $(0,0-0,4 \mathrm{~V})$ pouco definida o que é característico de ligas de PtRu [43]. Para o eletrocatalisador PtRuNi/C de razão nominal 50:40:10, observa-se na região de 
dupla-camada $(0,4-0,8 \mathrm{~V})$, um alargamento, isso provavelmente está relacionado a formação de óxidos de rutênio ou níquel.

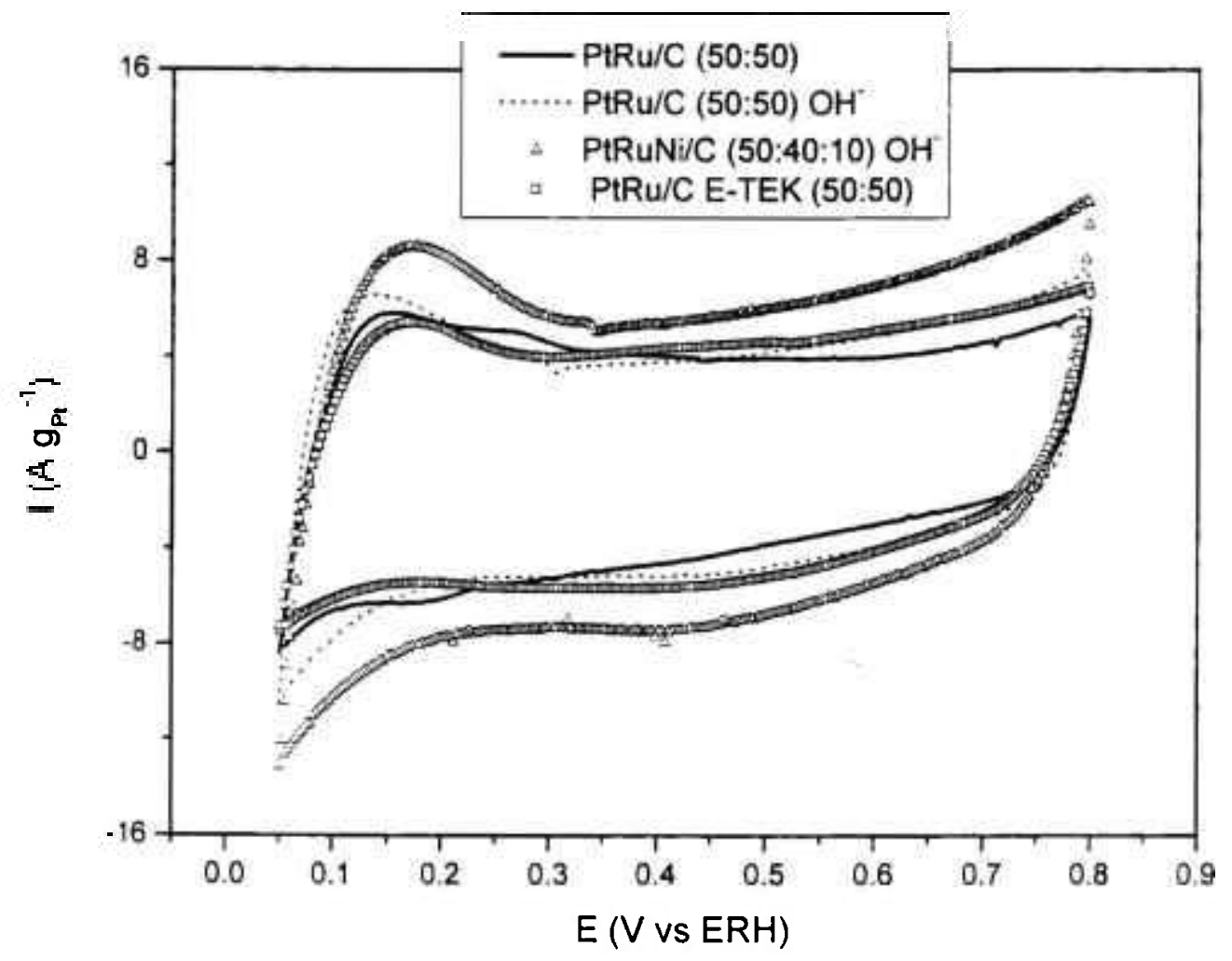

FIGURA 15 - Voltamogramas cíclicos obtidos em solução 0,5 mol.L.-1 de $\mathrm{H}_{2} \mathrm{SO}_{4}$ para os eletrocatalisadores PtRu/C E-TEK, PtRu/C e PtRuNi/C preparados pelo método da redução por álcool.

Nos voltamogramas cíclicos da FIG. 16 observa-se que os eletrocatalisadores começaram a eletro-oxidação do metanol em aproximadamente $0,3 \mathrm{~V}$. Observa-se que os eletrocatalisadores PtRu/C e PtRuNi/C preparados em meio alcalino apresentaram maiores valores de corrente que o eletrocatalisador $\mathrm{PtRu} / \mathrm{C}$ preparado em meio ácido. Isto pode ser explicado pelo menor tamanho de cristalito dos eletrocatalisadores preparados em meio alcalino. Observa-se que os eletrocatalisadores $\mathrm{PtRu} / \mathrm{C}$ (50:50) e PtRuNi/C (50:40:10) apresentaram desempenho semelhantes e maiores valores de corrente a partir de $0,5 \mathrm{~V}$ que o eletrocatalisador PtRu/C (50:50) preparado em meio ácido. Por voltametria ciclica o desempenho dos 
eletrocatalisadores preparados pelo método da redução por álcool apresentaram-se superior ao eletrocatalisador PtRu/C E-TEK.

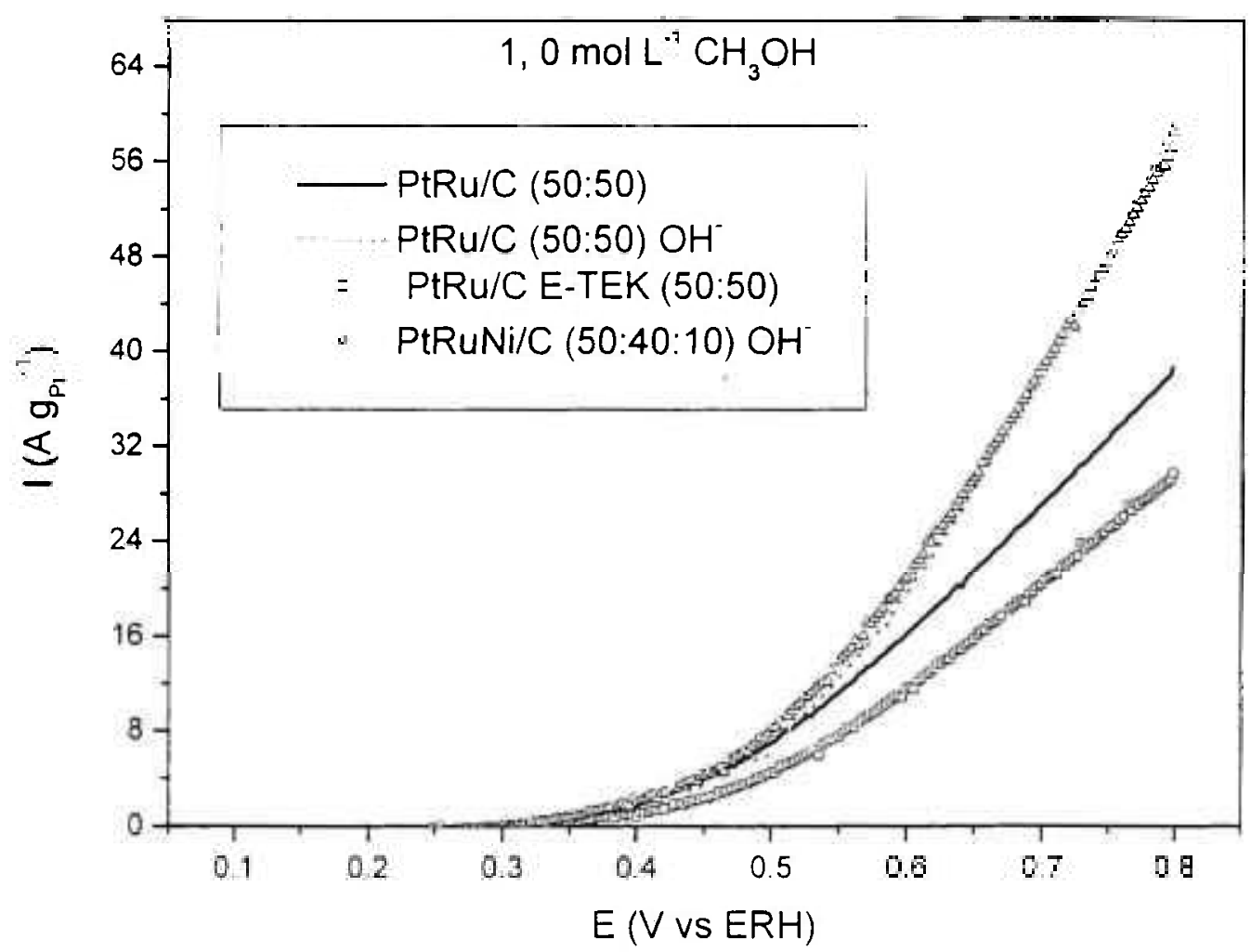

FIGURA 16 - Comparação dos valores de corrente para PtRu/C e PtRuNi/C preparados pelo método da redução por álcool na presença de $1,0 \mathrm{~mol} \cdot \mathrm{L}^{-1}$ de metanol, considerando-se apenas a varredura anódica, sendo esta corrigida pelo voltamograma base.

Na FIG. 17 são apresentados os estudos de cronoamperometria em 500 $\mathrm{mV}$ por $30 \mathrm{~min}$. Na análise por cronoamperometria um potencial $(\mathrm{V})$ é fixado e a corrente é medida ao longo do tempo. Dessa forma, podemos avaliar além do desempenho também a estabilidade do eletrocatalisador.

Os resultados mostraram que o eletrocatalisador PtRuNi/C 50:40:10 apresentou um melhor desempenho que o eletrocatalisador PtRu/C (50:50) preparado pelo método da redução por álcool em meio ácido e aicalino, e um desempenho similar ao eletrocatalisador PtRu/C E-TEK. Convém, ressaltar que os testes por voltametria ciclica FIG. 16 mostraram que os eletrocatalisadores PtRuNi/C e PtRu/C apresentaram um desempenho semelhante. Assim, estes 
resultados sugerem que a adição de $\mathrm{Ni}$ aos eletrocatalisadores PtRu/C preparados pelo método da redução por álcool leva a um aumento da estabilidade desses eletrocatalisadores. $O$ aumento da estabilidade dos eletrocatalisadores PtRuNi/C em relação aos eletrocatalisadores PtRu/C produzidos por essa metodologia também foi relatado por outros autores $[31,37]$.

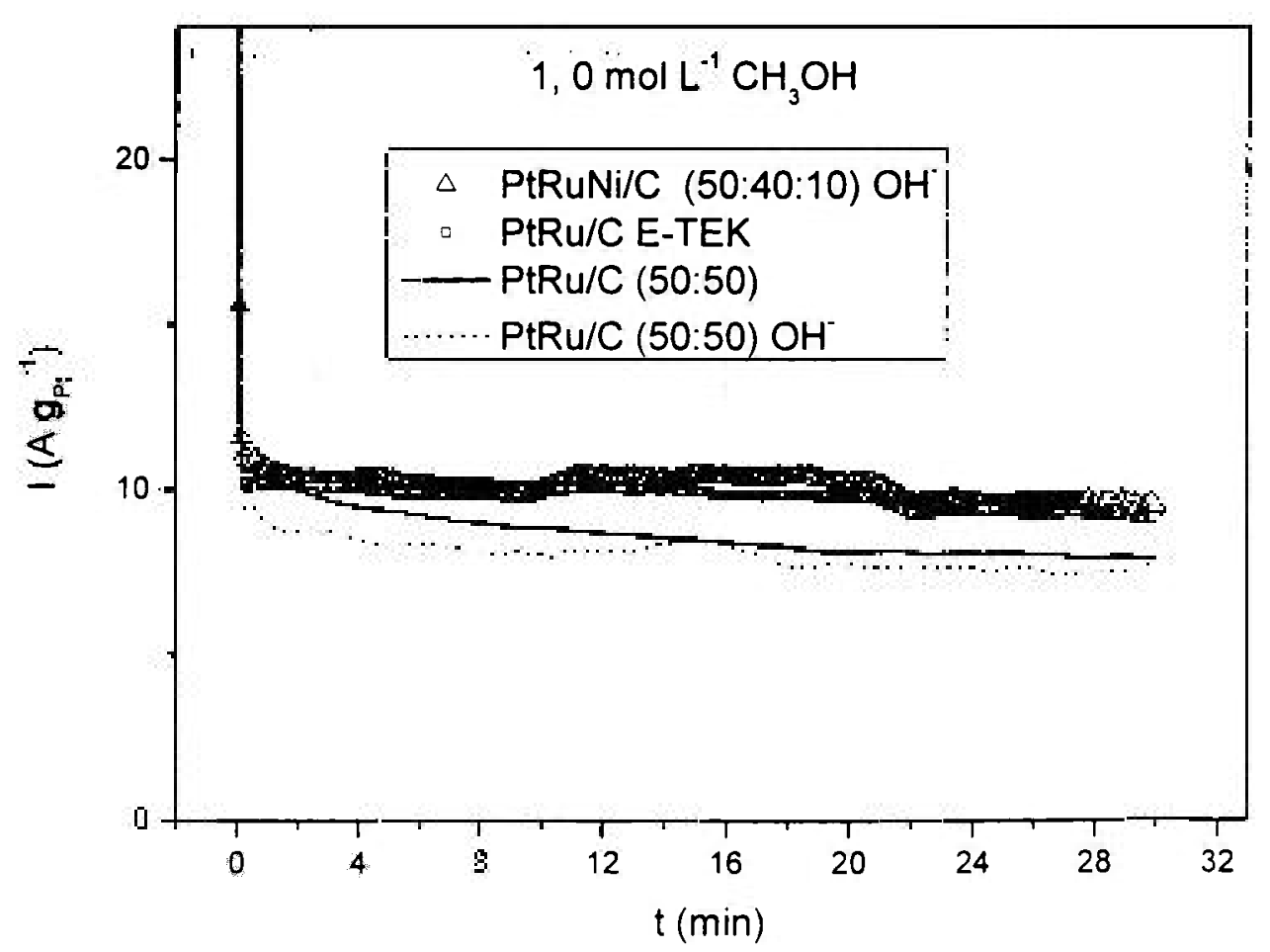

FIGURA 17 - Comparação das curvas cronoamperométricas para os eletrocatalisadores PtRu/C e PtRuNi/C com potencial fixo de $500 \mathrm{mV}$ por $30 \mathrm{~min}$.

4.3 Preparação de eletrocatalisadores PtRuNi/C com diferentes razôes atômicas Pt:Ru:Ni

Foram preparados eletrocatalisadores $\mathrm{PtRuNi/C}$ com diferentes razões atômicas Pt:Ru:Ni utilizando uma razão molar $\mathrm{OH}^{-} /$metais $=8 \mathrm{TAB} .3$. 
TABELA 3 - Razão atômica e tamanho médio de cristalito dos eletrocatalisadores PtRuNi/C preparados pelo método da redução por álcool com diferentes razôes atômicas Pt:Ru:Ni (razão molar $\mathrm{OH}^{-} /$metais=8).

\begin{tabular}{ccccc}
\hline catalisador & $\begin{array}{c}\text { Pt:Ru:Ni } \\
\text { nominal } \\
\text { (razão } \\
\text { atômica) }\end{array}$ & $\begin{array}{c}\text { Pt:Ru:Ni EDX } \\
\text { (razão } \\
\text { atômica) }\end{array}$ & $\begin{array}{c}\text { Tamanho de } \\
\text { médio de } \\
\text { cristalito } \\
\text { (nm) }\end{array}$ & $\begin{array}{c}\text { Massa de } \\
\text { metais TGA } \\
\text { (\%) }\end{array}$ \\
\hline PtRuNi/C & $70: 20: 10$ & $\mathbf{6 8 : 2 2 : 1 0}$ & $<2,0$ & 11 \\
PtRuNi/C & $60: 30: 10$ & $\mathbf{5 6 : 3 2 : 1 2}$ & $<2,0$ & 11 \\
PtRuNi/C & $50: 40: 10$ & $\mathbf{4 9 : 3 5 : 1 6}$ & $<2,0$ & 10 \\
PtRuNi/C & $50: 25: 25$ & $\mathbf{5 3 : 2 8 : 1 9}$ & $<2,0$ & 13 \\
& & & & 18 \\
PtRuNi/C & $50: 10: 40$ & $\mathbf{6 1 : 1 3 : 2 6}$ & $<2,0$ & 17 \\
& & & & \\
PtRuNi/C & $40: 30: 30$ & $\mathbf{4 2 : 3 7 : 2 1}$ & $<2,0$ & 17 \\
& & & & \\
\hline
\end{tabular}

A porcentagem $\in m$ massa de metais depositados no suporte de carbono para todos os casos foi menor que $20 \%$ FIG. 18. Para os eletrocatalisadores preparados com razões atômicas Pt:Ru:Ni de 70:20:10, 60:30:10 e 50:40:10 a massa de metais depositada no suporte de carbono foi de aproximadamente $11 \%$. Para o eletrocatalisador preparado com razão 50:25:25 observa uma deposição de $13 \%$, enquanto que, para os eletrocatalisadores preparados com razões 40:30:30 e 50:10:40 o valor encontra-se entre 17 e 18\%, mostrando que a deposição de metais no suporte de carbono aumenta com a quantidade de níquel. 


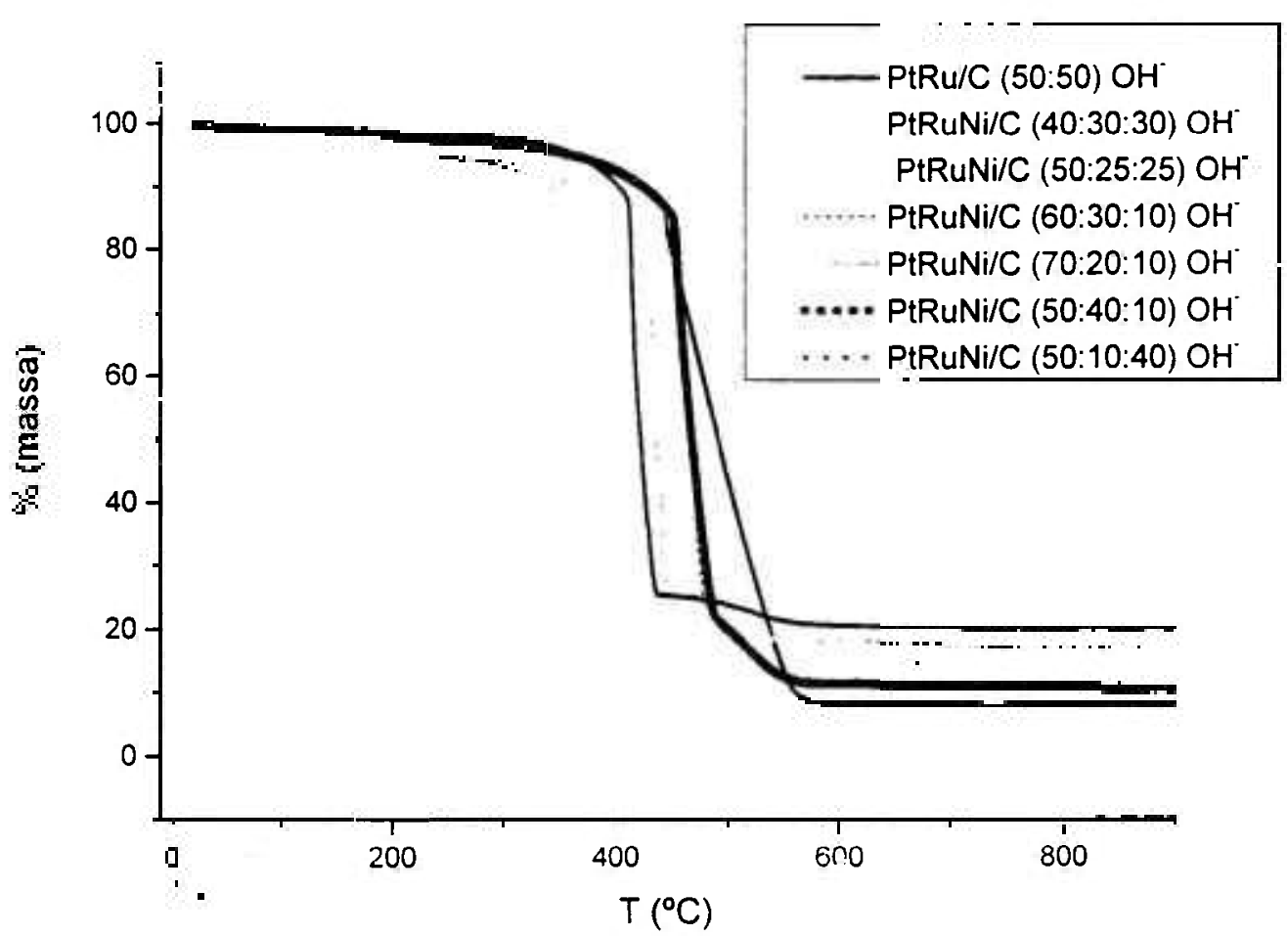

FIGURA 18 - Análises Termogravimétricas PtRu/C, temperatura ambiente até $900^{\circ} \mathrm{C}$, com uma de aquecimento igual a $5^{\circ} \mathrm{C} \cdot \mathrm{min}^{-1}$ em atmosfera de oxigênio $\operatorname{seco}\left(30 \mathrm{~mL} \cdot \mathrm{min}^{-1}\right)$.

Na FIG. 19 são mostrados os difratogramas de raios $X$ dos eletrocatalisadores PtRuNi/C preparados com diferentes razões atômicas. Para todos os eletrocatalisadores PtRuNi/C são observados os picos relativos à fase CFC de Pt e suas ligas, não sendo observado picos relativos a outros fases. Apesar disso, a presença de outras fases (amorfas) não podem ser excluidas. 


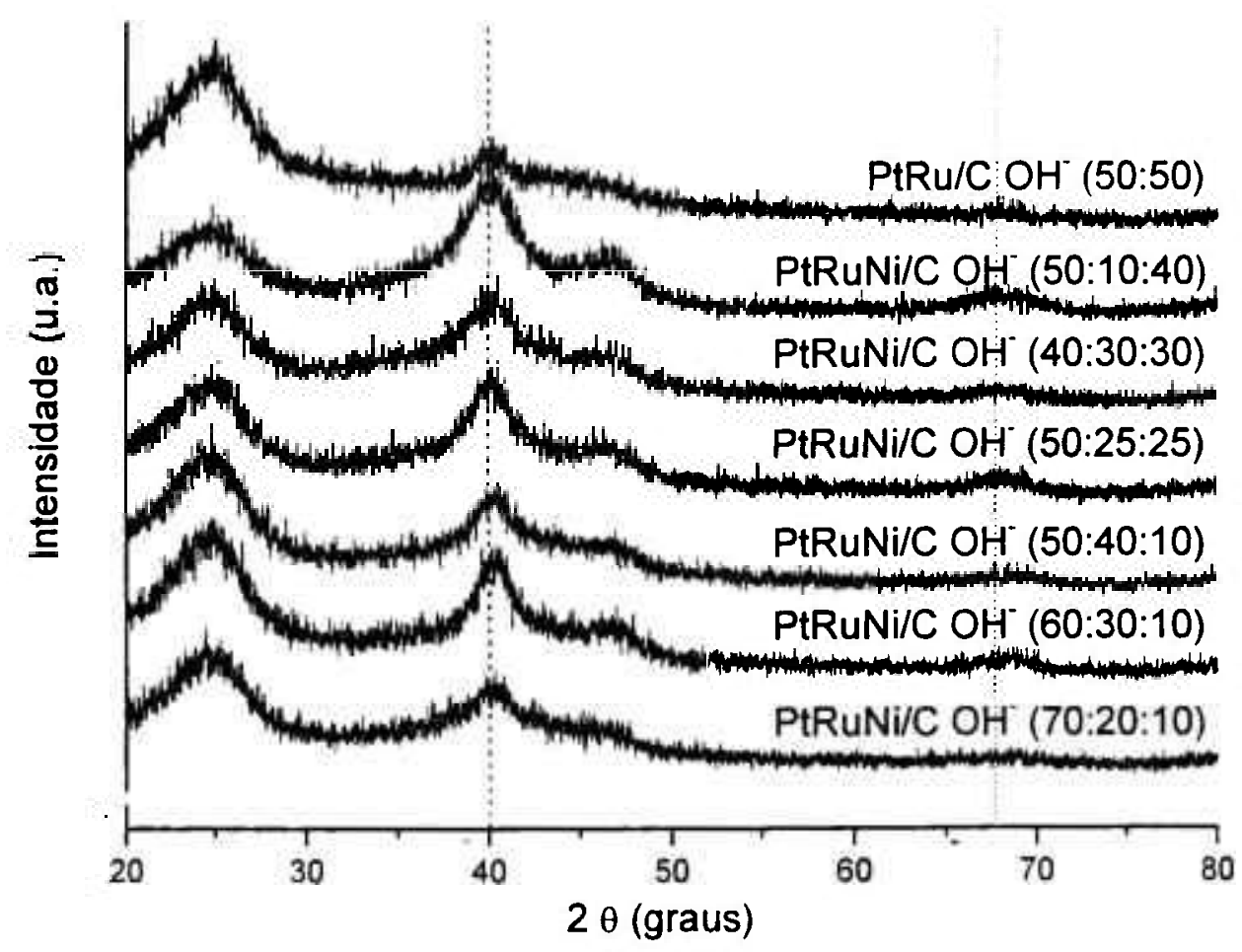

FIGURA 19 - Difratogramas de raios $X$ dos eletrocatalisadores PtRuNi/C preparados pelo método de redução por álcool com diferentes razões atômicas.

$\mathrm{Na}$ FIG. 20 são mostrados os voltamogramas lineares, para os eletrocalisadores PtRuNi/C preparados com diferentes razões atômicas. Observa-se para todos os eletrocatalisadores PtRuNi/C que a eletro-oxidação do metanol começa em aproximadamente em 0,3 V. O eletrocatalisador PtRuNi/C com razão atômica 50:40:10 apresenta maiores valores de corrente na faixa de potencial de interesse em DMFC $(0,2-0,6 \mathrm{~V})$. 


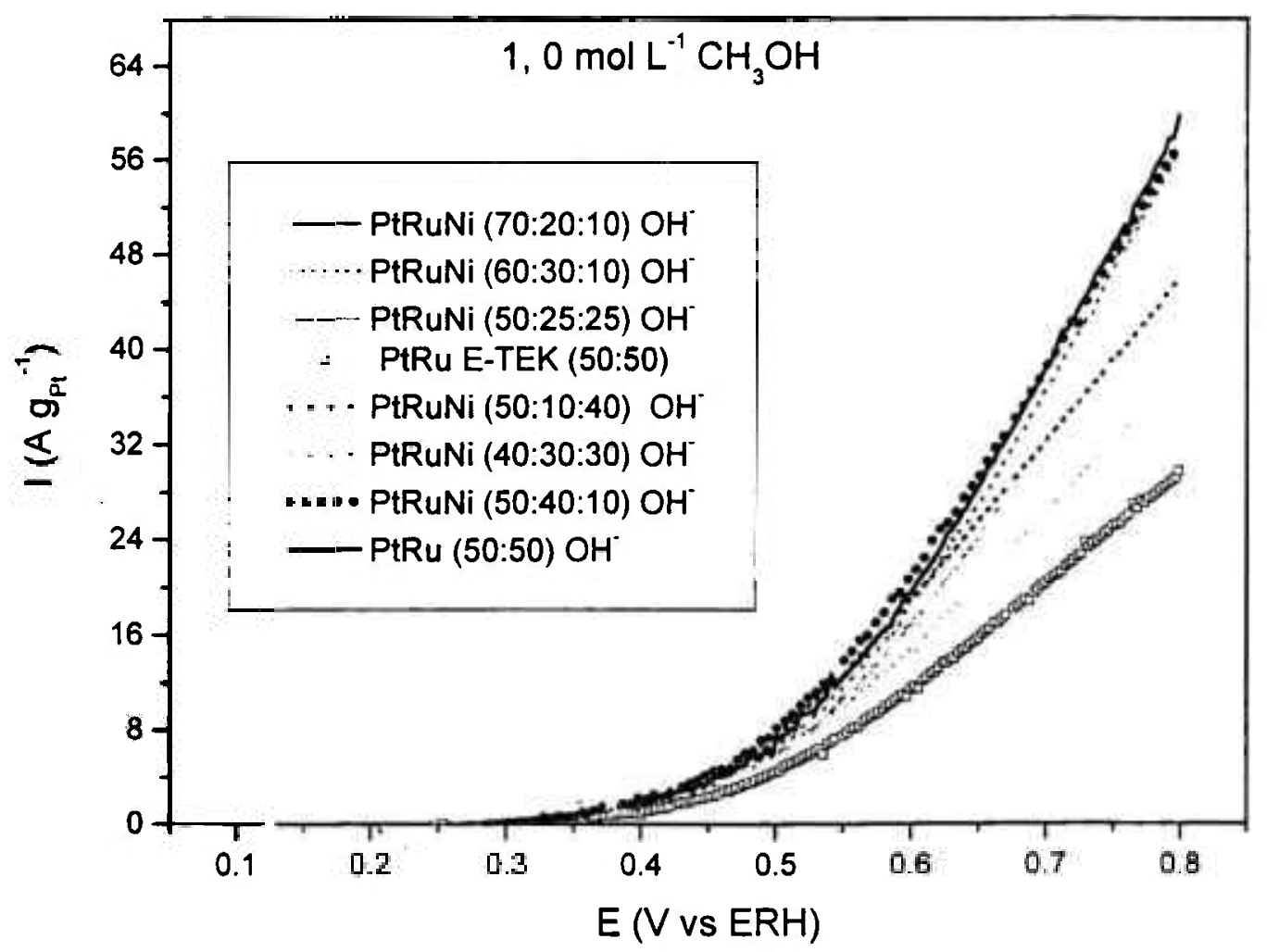

FIGURA 20 - Comparação dos valores de corrente para PtRu E-TEK e PtRuNi/C preparados pelo método da redução por álcool na presença de 1,0 $\mathrm{mol} \cdot \mathrm{L}^{-1}$ de metanol, considerando-se apenas a varredura anódica, sendo esta corrigida com relação ao voltamograma base.

Na FIG. 21 são apresentados os estudos de cronoamperometria em 500 $\mathrm{mV}$ por $30 \mathrm{~min}$. De um modo geral, os eletrocatalisadores PtRuNi/C preparados com diferentes razões atômicas apresentaram um desempenho similar ou superior as eletrocatalisador PtRu/C preparado pela mesma metodologia da sintese PtRu/C, mostrando o efeito benéfico da adição de niquel. Dentre os eletrocatalisadores $\mathrm{PtRuNi/C}$ preparados com diferentes razões atômicas; o eletrocatalisador preparado com razão atômica PtRuNi de 50:40:10 apresentou o melhor desempenho e este foi ligeiramente superior ao do eletrocatalisador comercial PtRu/C E-TEK. 


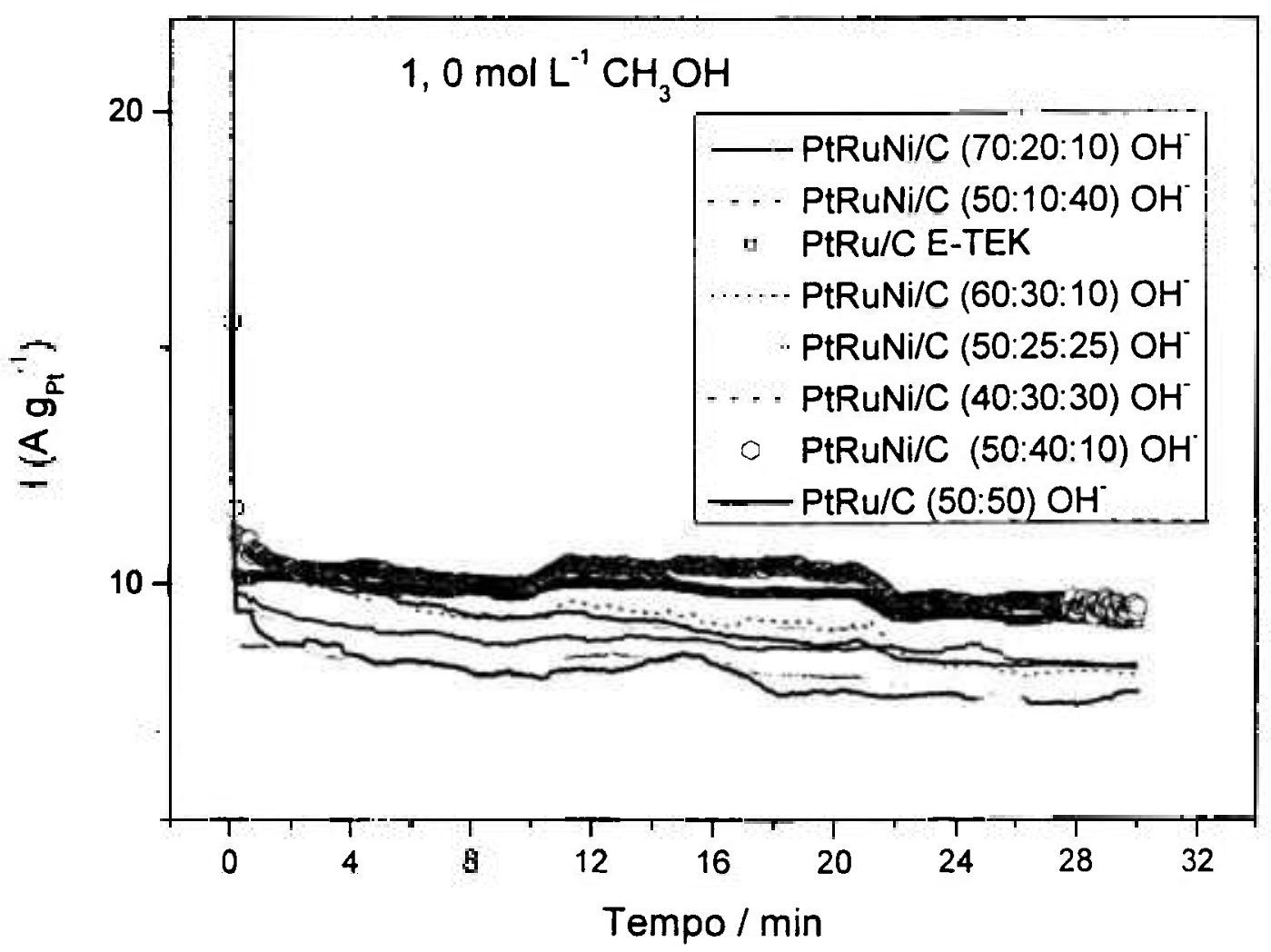

FIGURA 21 - Comparação das curvas cronoamperométricas para os eletrocatalisadores PtRu E-TEK e PtRuNi/C com potencial fixo de $500 \mathrm{mV}$ por $30 \mathrm{~min}$.

Como observado por outros autores [31-37] a adição de uma pequena quantidade de Niquel ao eletrocatalisadores PtRu/C (50:50) parece ser suficiente para obter materiais mais ativos e estáveis. Neste caso, o material com razão Pt:Ru:Ni 50:40:10 apresentou-se como o mais ativo, no entanto, nas condições de sintese (razão molar $\mathrm{OH}^{-} / \mathrm{Me}=8$ ) nem todas as nanopartículas formadas depositaram no suporte de carbono. Observou-se nos meios reacionais, depois da separação do eletrocatalisadores por filtração, que após o periodo de alguns dias ocorria a formação de um filme metálico na superfície dos mesmos. Este filme foi provavelmente formado pela aglomeração das nanopartículas, que se encontravam estabilizadas em solução pelos ions $\mathrm{OH}^{-}$, e que não depositaram no suporte de carbono nas condições de sintese utilizada. 
Recentemente foi mostrado para eletrocatalisadores Pt/C preparados utilizando etileno glicol como agente redutor que o $\mathrm{pH}$ do meio reacional tem um importante papel no controle do tamanho de partículas e na deposição das nanoparticulas no suporte de carbono [47].

Assim, para os materiais preparados com razōes $\mathrm{OH}^{-} / \mathrm{Me}=8$, a superficie das nanopartículas e do suporte de carbono provavelmente encontravam-se carregadas negativamente o que dificulta a deposição das nanopartículas sobre o suporte.

NA FIG. 22 é mostrada a imagem obtida por microscopia eletrônica de trasmissão (MET) do eletrocatalisador PtRuNi/C (50:40:10) com razão molar $\mathrm{OH}^{-} / \mathrm{Me}=8$.

Observa-se uma boa dispersão da nanopartículas sobre o suporte de carbono estas apresentam um tamanho médio de $2,5 \pm 0,5 \mathrm{~nm}$.

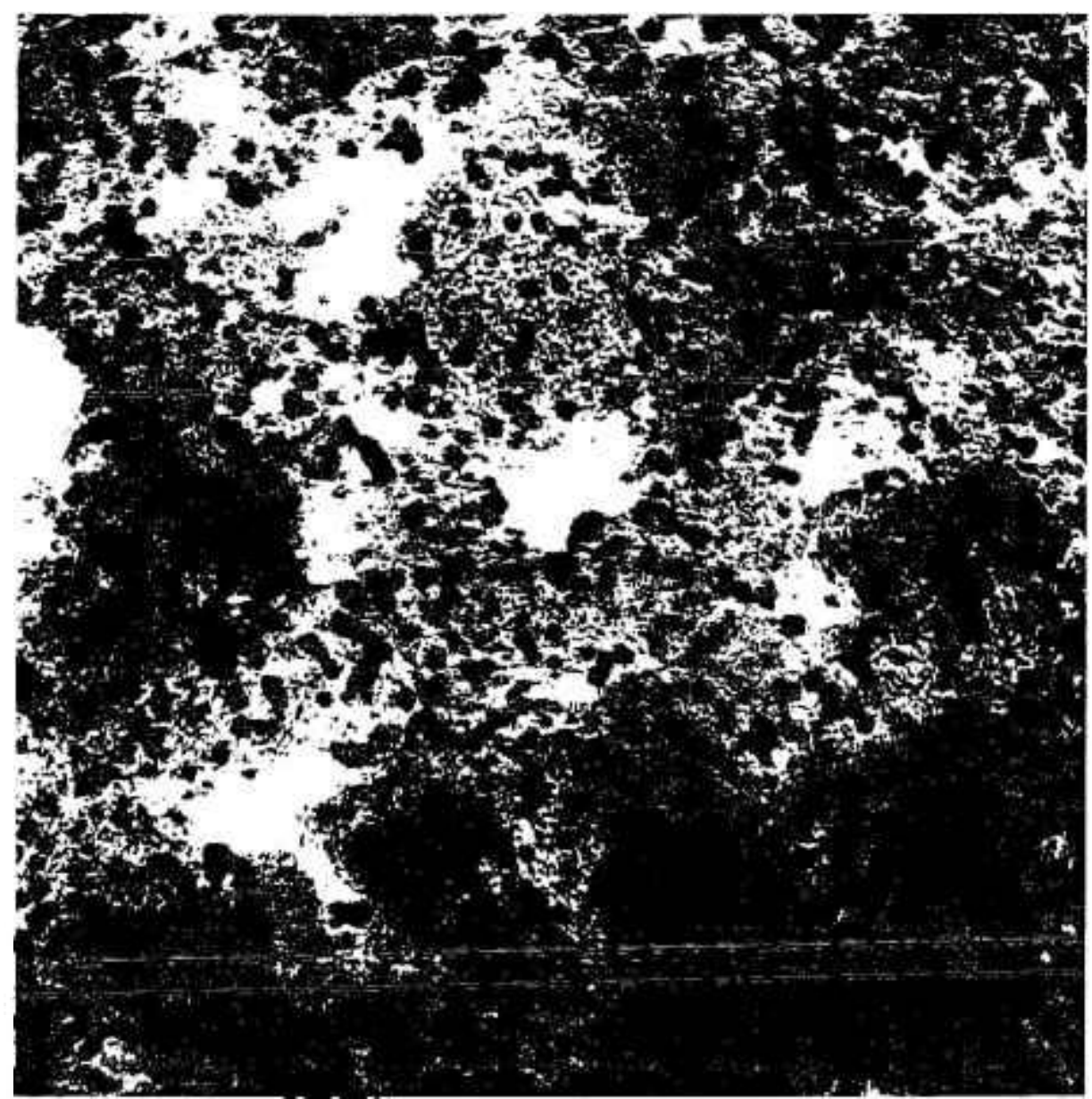

FIGURA 22 - Micrografia eletrônica de transmissão do eletrocatalisador PtRuNi/C 50:40:10 preparado com razão $\mathrm{OH} / \mathrm{Me}=8$ (a barra corresponde a 10 $\mathrm{nm})$. 
4.4 Preparação do eletrocatalisador PtRuNi/C (50:40:10) variando a razão molar OH $/$ metais.

Foi realizado um estudo da razão $\mathrm{OH}^{-} /$metais visando à redução total dos íns metálicos, bem como, a deposição total das nanoparticulas formadas no suporte de carbono. Para isso, a razão $\mathrm{OH}^{-} /$metais foi variada entre 4 e 12 e os resultados são mostrados na TAB. 4.

TABELA 4 - Razão atômica e tamanho médio de cristalitos dos eletrocatalisadores PtRuNi/C 50:40:10 variando a razão $\mathrm{OH}^{-} /$metais

\begin{tabular}{|c|c|c|c|c|c|}
\hline catalisador & $\begin{array}{c}\text { Razão } \\
\text { atômica } \\
\mathrm{OH}^{-} \\
\text {/metais }\end{array}$ & $\begin{array}{l}\text { Pt:Ru:Ni } \\
\text { nominal } \\
\text { (razão } \\
\text { atômica) }\end{array}$ & $\begin{array}{c}\text { Pt:Ru:Ni } \\
\text { EDX } \\
\text { (razão } \\
\text { atômica) }\end{array}$ & $\begin{array}{l}\text { Tamanho } \\
\text { médio de } \\
\text { cristalito } \\
\text { (nm) }\end{array}$ & $\begin{array}{c}\text { Massa de } \\
\text { metais } \\
\text { TGA (\%) }\end{array}$ \\
\hline PtRuNi/C & 4 & $50: 40: 10$ & $50: 48: 02$ & 2,0 & 20 \\
\hline PtRuNi/C & 5 & $50: 40: 10$ & $50: 46: 04$ & $<2,0$ & 20 \\
\hline PtRuNi/C & 6 & $50: 40: 10$ & $43: 41: 16$ & $<2,0$ & 11 \\
\hline PtRuNi/C & 7 & $50: 40: 10$ & $48: 39: 13$ & $<2,0$ & 11 \\
\hline PtRuNi/C & 8 & $50: 40: 10$ & 493516 & $<2,0$ & 10 \\
\hline PtRuNi/C & 10 & $50: 40: 10$ & $53: 37: 10$ & 2,7 & 14 \\
\hline PtRuNi/C & 12 & $50: 40: 10$ & $42: 37: 21$ & 3,4 & 13 \\
\hline
\end{tabular}


As análises por EDX mostram que, para razões $\mathrm{OH}^{-} /$metais de 4 e 5 as razões atômicas obtidas são diferentes das razões nominais, sugerindo que os ions $\mathrm{Ni}$ (II) não foram reduzidos nestas condições. O testes qualitativos com dimetilglima realizados nestes meios reacionais após a separação do eletrocatalisador confirmou a presença de ions Ni (II). Para as razões $\mathrm{OH}^{-}$ /metais entre 6 e 12 as razoes atômicas atômicas obtidas por EDX são semelhantes às razões nominais e o teste qualitativo de íons $\mathrm{Ni}$ (II) não mostrou a presença deste nestes meios.

Para os eletrocatalisadores PtRuNi/C FIG. 23 preparados utilizando uma razão molar $\mathrm{OH} /$ metais de 4 e 5 a massa de metais depositada no suporte de carbono foi cerca de $20 \%$, no entanto, nestas condições a redução e incorporação dos ions $\mathrm{Ni}$ (II) nas nanopartículas não ocorreu. Para os eletrocatalisadores preparados com razões $\mathrm{OH}^{-} /$metais entre 6 e 12, apesar de ocorrer redução dos ions $\mathrm{Ni}$ (II) riestas condições, a massa de metais depositada no suporte de carbono ficou entre 11 e 14 FIG. 23.

Recentemente, um estudo do efeito de $\mathrm{Pt}$ na preparação de eletrocatalisador PtRu/C utilizando etileno glicol como agente redutor mostrou que em condições similares às utilizadas neste trabalho, somente cerca da metade da massa de metais também foi depositada no suporte de carbono [48]. 


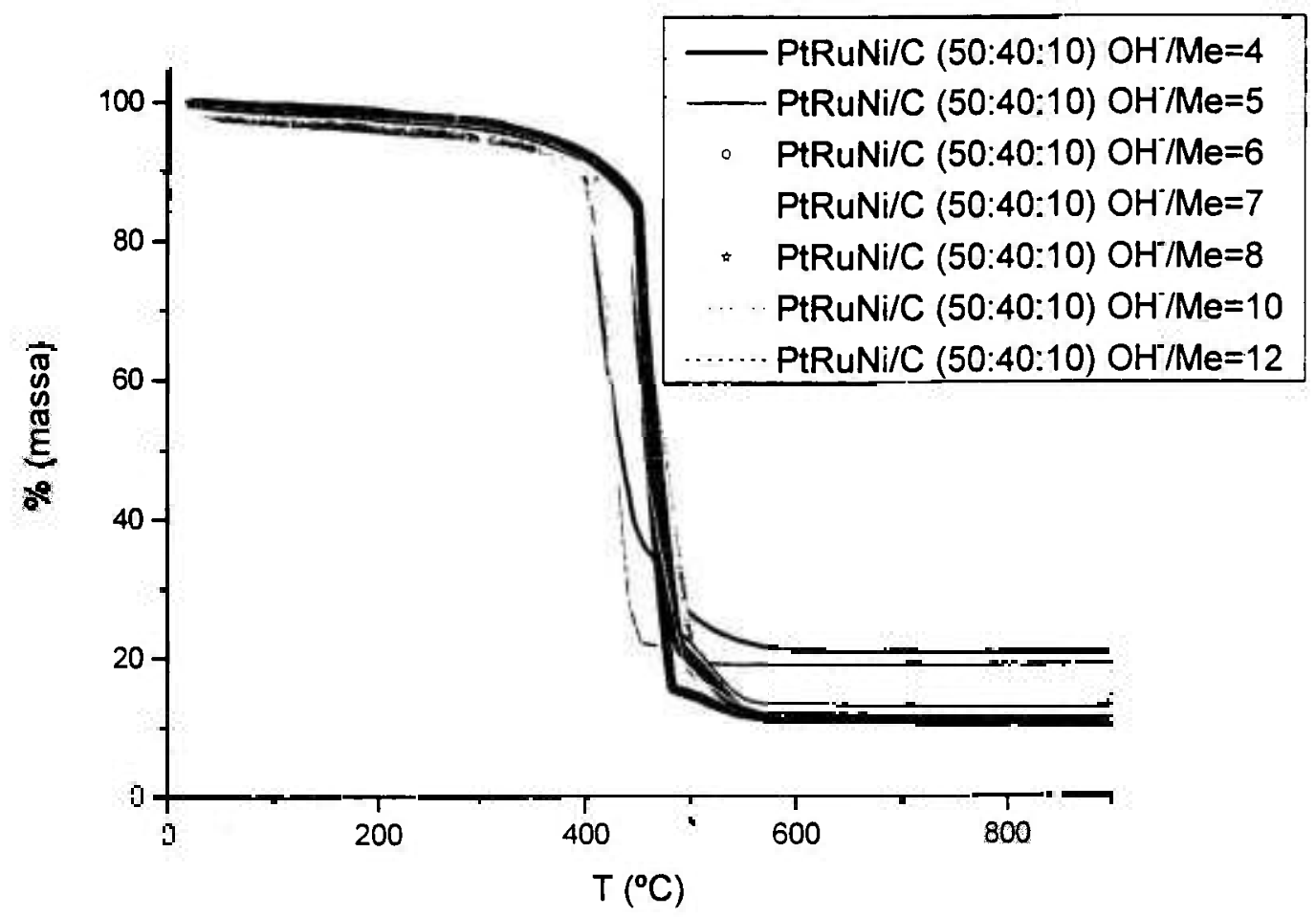

FIGURA 23 - Análises Termogravimétricas PtRu/C, temperatura ambiente até $900{ }^{\circ} \mathrm{C}$, com uma taxa de aquecimento igual a $5{ }^{\circ} \mathrm{C} \cdot \mathrm{min}^{-1} \mathrm{em}$ atmosfera de oxigênio seco $\left(30 \mathrm{~mL} \cdot \mathrm{min}^{-1}\right)$.

$\mathrm{Na}$ FIG. 24 são mostrados os difratogramas de raios $X$ dos eletrocatalisadores PtRuNi/C preparados por diferentes razões $\mathrm{OH}^{-1 / m e t a i s . ~} \mathrm{O}$ material preparado com razão molar $\mathrm{OH}^{-} /$metais de 4 apresentou um tamanho médio de cristalito de $2 \mathrm{~nm}$ TAB. 4. Para os materiais preparados com razões $\mathrm{OH} /$ metais entre 5 e 8 , os tamanhos de cristalito apresentaram-se menores que $2 \mathrm{~nm}$; enquanto que, o materiais preparados com razões 10 e 12 apresentaram tamanhos de cristalito de 2,7 e 3,4, respectivamente. Para todo os eletrocatalisadores, são observados os picos característicos da CFC de Pt e suas ligas. Para os materiais preparados com razões $\mathrm{OH}^{-} /$metais entre 6 e 12 observa um pequeno deslocamento de picos relativos a fase CFC para ângulos maiores quando comparados aos materiais preparados com razōes $\mathrm{OH}^{-1} /$ metais de 4 e 5 , onde não ocorre a incoporação de $\mathrm{Ni}$. Isto sugere, portanto, a incorporação de $\mathrm{Ni}$ na fase $\mathrm{CFC}$ de $\mathrm{Pt}$ para os materiais preparados com razões entre 6 e 12 . 


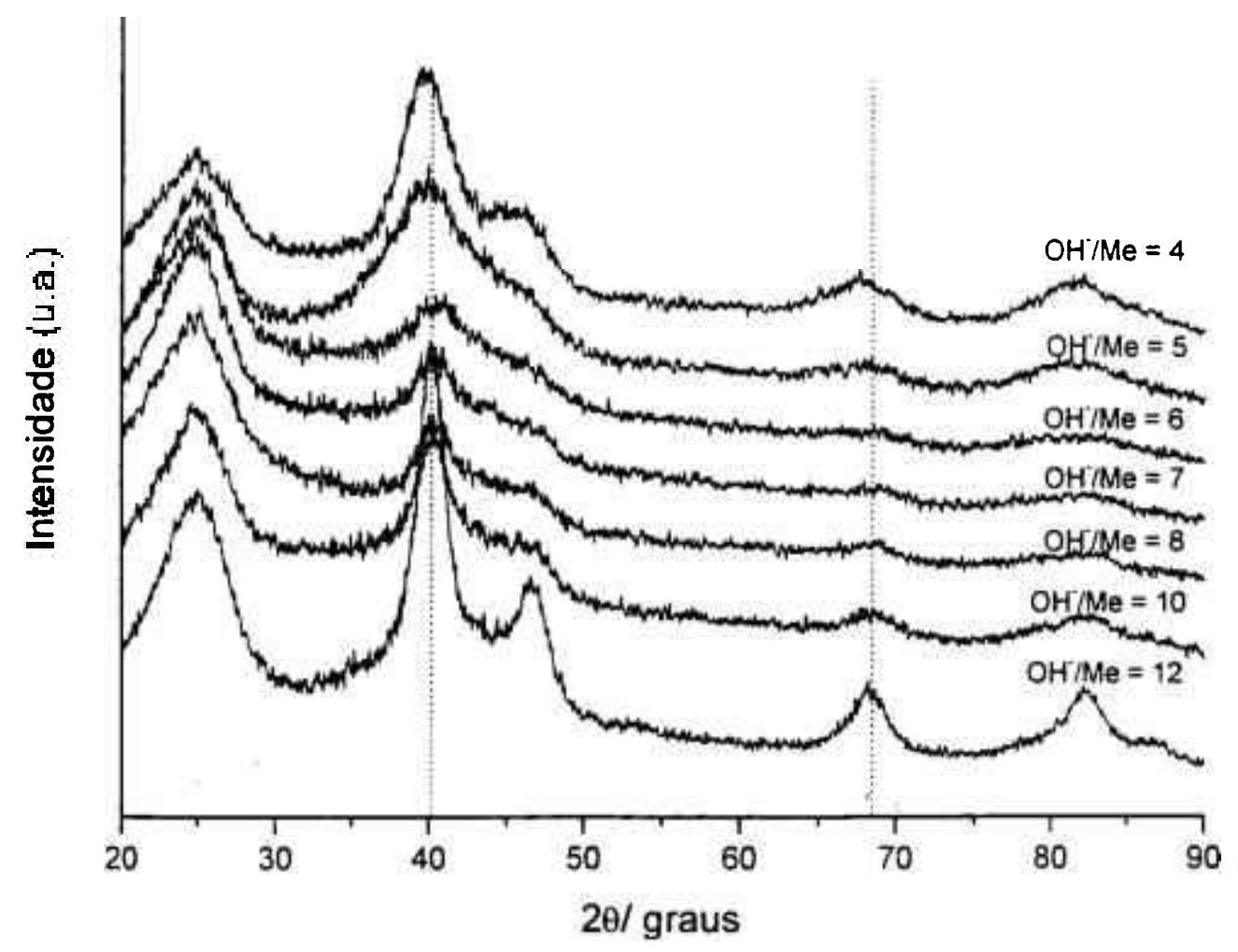

FIGURA 24 - Difratogramas de raios $X$ dos eletrocatalisadores PtRuNi/C 50:40:10 preparado com diferentes razôes $\mathrm{OH}^{-} /$metais.

Na FIG. 25 são apresentados os voltamogramas cíclicos em solução 0,5 mol. $L^{-1}$ de $\mathrm{H}_{2} \mathrm{SO}_{4}$ dos eletrocatalisadores PtRuNi/C preparados com diferentes razões $\mathrm{OH}^{\%} /$ metais. Observa-se para todos os eletrocatailisadores a região de adsorção-dersoção de hidrogênio $(0,0$ - 0,4 V) pouco definida e um alargamento da região de dupla-camada $(0,4-0,8 \mathrm{~V})$, sendo que este alargamento é menor para os eletrocatalisadores obtidos com tamanhos de cristalitos menores que 2nm (razão molar $\mathrm{OH}^{-} /$metais entre 5 e 8 ), o que talvez possa ser atribuido a maior quantidade de especiais oxigenadas na superfície destes eletrocatalisadores [43]. 


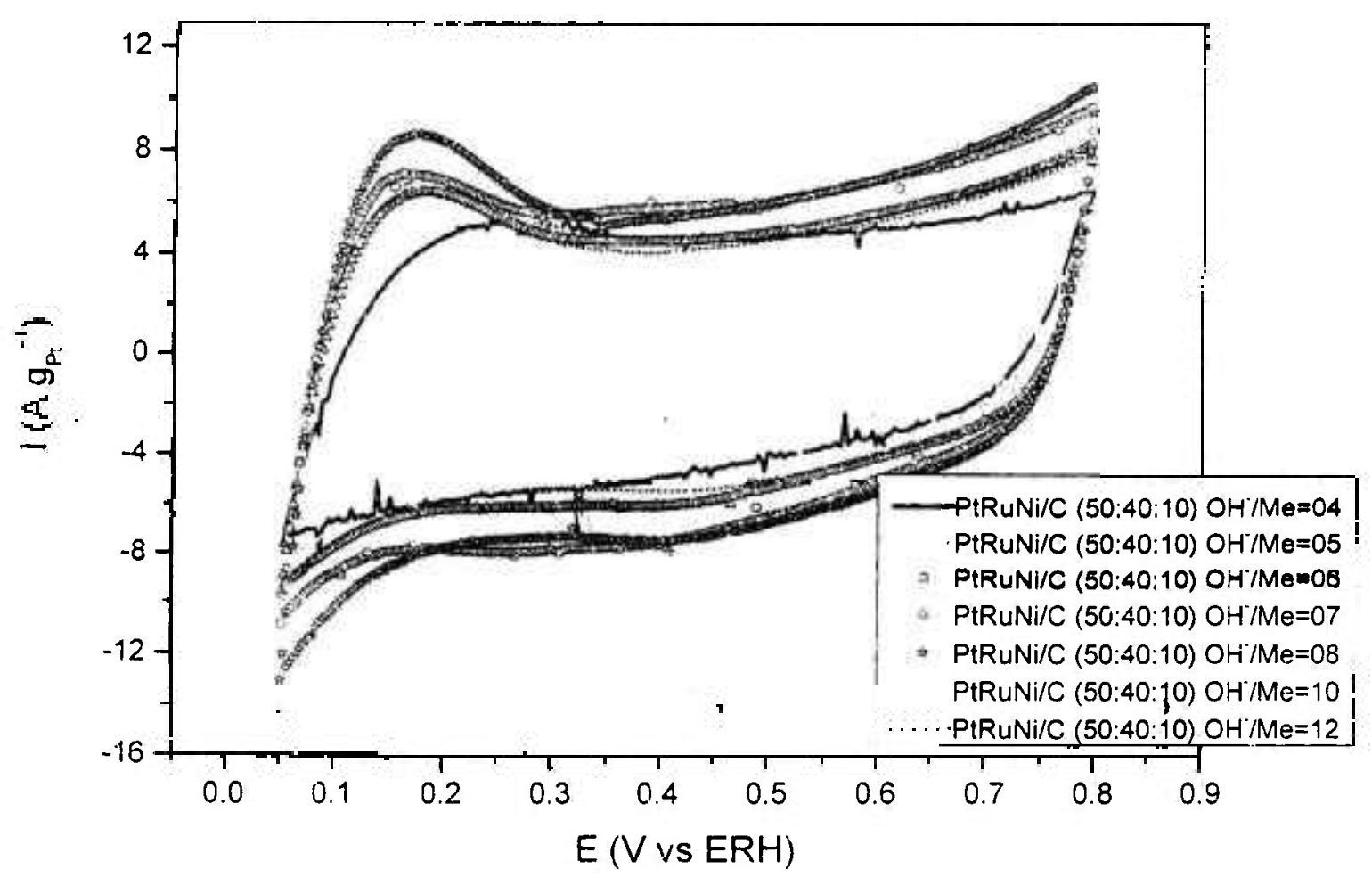

FIGURA 25 - Voitamogramas cíclicos obtidos em solução $0,5 \mathrm{~mol}^{-L^{-1}}$ de $\mathrm{H}_{2} \mathrm{SO}_{4}$ para o eletrocatalisadores PtRuNi/C preparados pelo método da redução por álcool.

Na FIG 26 são apresentados os estudos de cronoamperometria em 500 $\mathrm{mV}$ por $30 \mathrm{~min}$. De um modo geral, os eletrocatalisadores preparados com menor tamanho de cristalitos e nos quais os ions $\mathrm{Ni}$ (II) foram incorporados apresentam, os melhores desempenhos. Assim, o eletrocatalisador preparado com razão molar $\mathrm{OH}^{-} /$metais de 6 apresentou o melhor desempenho seguido do eletrocatalisador com razão molar $\mathrm{OH}^{-1} /$ metais de 7 . Vale ressaltar, que estes eletrocatalisadores apresentaram desempenhos bem superiores na eletrooxidação do metanol que o eletrocatalisador PtRu/C comercial. 


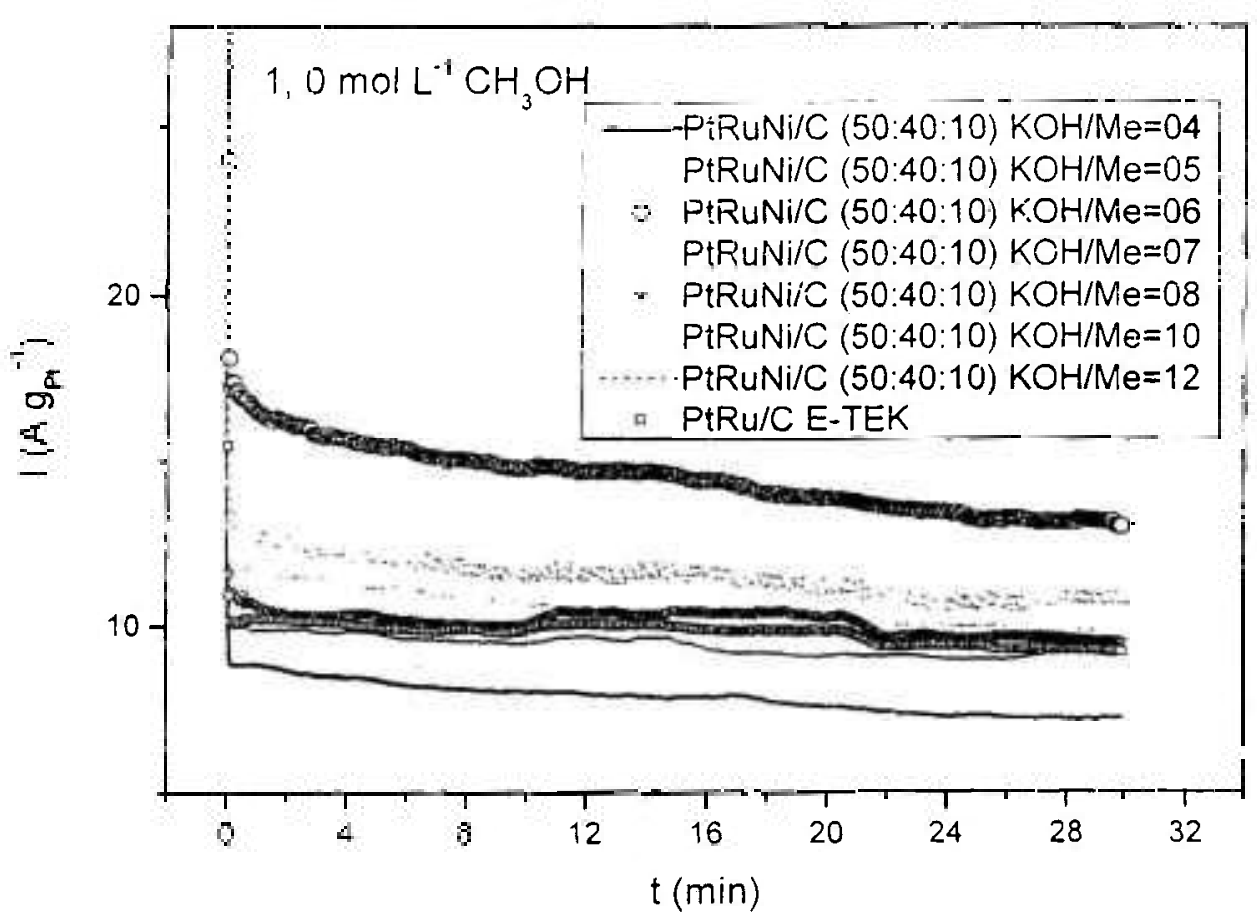

FIGURA 27 - Comparação das curvas cronoamperométricas para os eletrocatalisadores $\mathrm{PtRuNi} / \mathrm{C}$ variando o $\mathrm{pH}$ do meio reacional com potencial fixo de $500 \mathrm{mV}$ por $30 \mathrm{~min}$. 


\section{CONCLUSÕES}

Na preparação dos eletrocatalisadores PtRuNi/C pelo método da redução por álcool observou-se que quando a síntese é realizada em meio ácido observase apenas a redução dos ions Pt(IV) e Ru(III), enquanto que os ions Ni(II) permaneceram em solução. A redução dos ions $\mathrm{Ni}(I I)$ e sua incorporação nas nanoparticulas metálicas ocorreu somente em meio alcalino. Neste caso observou-se para as nanoparticulas formadas uma estrutura cúbica de face centrada caracteristica de Pt e suas ligas e também um menor tamanho. Por outro lado, a quantidade de metais depositada no suporte de carbono foi de apenas cerca da metade da utilizada na síntese.

O estudn da variação da razão atômica Pt:Ru:Ni (70:20:10, 60:30:10, 50:40:10, 50:25:25, 50:10:40 e 40:30:30) utilizando uma razão atômica $\mathrm{OH}^{-} /$metais de 8 mostrou que os materiais obtidos apresentaram razões atômicas Pt:Ru:Ni semelhantes as razões nominais. Um aumento da quantidade de metais (\% massa) depositada no suporte de carbono foi observado com o aumento da quantidade de $\mathrm{Ni}$. No entanto, a deposição da quantidade total de metais no suporte de carbono não foi observada em nenhum caso. Nestas condições, 0 eletrocatalisador PtRuNi/C com razão atômica 50:40:10 apresentou-se o mais ativo na eletro-oxidação do metanol.

$O$ estudo do efeito da razão molar $\mathrm{OH}^{\%}$ metais (faixa entre 4 e 12) para o eletrocatalisador PtRuNi/C (50:40:10) visando a redução total dos íons metálicos, bem como, a deposição total das nanopartículas formadas no suporte de carbono, mostrou que a redução dos ions Pt(IV) e Ru(III) ocorreu em toda a faixa estudada, no entanto, a redução dos ions $\mathrm{Ni}(\mathrm{II})$ só ocorreu a partir de uma razão atômica $\mathrm{OH}^{-}$ /metais igual a 6 . Para valores $\mathrm{OH}^{-} /$metais entre 5 a 8 os tamanhos de cristalito apresentaram-se menores que $2 \mathrm{~nm}$, enquanto que, para valores menores que $5 \mathrm{e}$ maiores que 10 ocorreu um aumento nos tamanhos. Por outro lado, a deposição total de metais sobre o suporte só foi observada para valores $\mathrm{OH}^{-} /$metais menores que 6 onde a redução dos ions $\mathrm{Ni}($ II) não ocorre. Portanto, nas condições estudadas, não foi possivel encontrar as melhores condições, que permitam a 
reciução dos ions $\mathrm{Ni}(\mathrm{II})$ e a deposiçăo total das nanoparticulas formadas no suporte de carbono. No entanto, como também observado por outros autores utilizando metodologias de preparaçảo diferentes, os resultados obtidos neste trabalho mostram também que a incorporação do $\mathrm{Ni}$ nos eletrocatalisadores PtRu/C permitiu obter materiais mais ativos e estáveis para a eletro-oxidação do metanol. 


\section{SUGESTÕES PARA TRABALHOS FUTUROS}

- Verificar se existe um valor "ideal" da razão $\mathrm{OH}^{-} /$metais localizado entre os valores 5 e 6 em que possa ocorrer a redução dos íns $\mathrm{Ni}(\mathrm{II})$ e a deposição totai das nanopartículas formadas no suporte de carbono.

- Testar outros álcoois de maior ponto de ebulição, como por exemplo, dietileno glicol, trietileno glicol, etc, o que talvez possibilite a redução dos ions $\mathrm{Ni}(\mathrm{II})$ em uma faixa mais ampla de $\mathrm{pH}$.

- Analisar os eletrocatalisadores obtidos por técnicas de superfície, como por exemplo, XPS, com o objetivo de identificar as razões atômicas Pt:Ru:Ni da superficie e também a forma em que estes metais se encontram. Estas informações podem contribuir para um melhor entendimento do comportamento catalitico destes materiais.

- Testar estes eletrocatalisadores em células unitárias alimentadas diretamente com metanol a fim de avaliá-los em condições reais de operação. 


\section{REFERÊNCIAS BIBLIOGRÁFICAS}

[1] MELLE, F. D. The global and urban environment: the need for clean power systems. J. Power Sources, v. 71, p. 7-11, 1998.

[2] VIELSTICH, W., LAMM, A., GASTEIGER, A. H., CHICHEESTER, W. Fuel cells technology and applications. Handbook of Fuel Cells. v. 1 e 3, 2003.

[3] CARMO, M. d. Preparação e avaliação de eletrocatalisadores suportados em nanotubos de carbono para a oxidação de motanol, Dissertação (Mestrado) - 2003 São Carlos Universidade de São Paulo, São Paulo.

[4] GONZALEZ, E. R. Eletrocatálise e poluiçăo ambiental. Química Nova, v 23, p. 262, 2000.

[5] WENDT, H.; LINARDI, M.; ARICÓ, E. M. Células a combustivel de baixa potência para aplicações estacionárias. Química Nova, v. 25, p. $470,2002$.

[6] ZEGERS, P. Fuel cell commercialytion: The key to a hydrogen economy. Journal of Power Sources, v. 154, p. 497, 2006.

[7] WENDT, H.; GOTZ, M.; LINARDI, M. Tecnologia de células a combustível. Química Nova, v. 23, p. 538, 2000.

[8] TICIANELLI, E. A., CAMARA, C. A., SANTOS, L.G.A. Eletrocatalise das reações de oxidação de hidrogênio e de redução de oxigênio. Química Nova, v. 28, p. 664, 2005.

[9] IWASITA, T. Electrochim. Electrocatalysis of methanol oxidation. Electrochimica Acta, v. 47, p. 3663, 2002.

[10] WATANABE, M.; MOTOO, S. Electrocatalysis by ad-atoms. Part III. Enhacement of the oxidation of carbon monoxide on platinum by ruthenium ad-atoms. Journal Electroanalytical Chemestry, v.60, p.275-283, 1975.

[11] HAMNET, A. Mechanism and electrocatalysis in the direct methanol fuel cell. Catalysis Today, v.38, p.445-457, 1997.

[12] FREELINK, T.; VISSCHER, W.; VEEN VAN, J.A.R. On the role of Ru and $\mathrm{Sn}$ as promoters of methanol electrooxidation over Pt. Surface Science, v.335, p.353-360, 1995.

[13] WATANABE, M.; MOTOO, S. Electrocatalysis by ad-atoms part II. Enhancement of the oxidation of methanol on platinum by ruthenium ad-atoms. Journal of Electroanalytical Chemistry, v.60, n.3, p.267$273,1975$. 
[14] CHAN, K-Y., DING, T., REN, J., CHENG, S., TSANG, K. Y. Supported mixed metal nanoparticles as electrocatalysts in low tempetature fuel cells. Journal of Materials Chemistry, v. 14, p. 505 , 2004.

[15] GASTEIGER, H.A.; MARKOVIC, N.; ROSS JR, P.N.; CAIRNS, E.J. Methanol electrooxidation on well-characterized Pt-Ru alloys. Journal of Physical. Chemistry, v.97, p.12020-12029, 1993.

[16] LAMY, C.; LIMA, A.; LERHUN, V.; DELIME, F.; COUTANCEAU, C.; LEEGER, J-M. Recent advances in the development of direct alcohol fuel cells (DAFC). Journal of Power Sources, v. 105, p. 283, 2002.

[17] FREELINK, T.; VISSCHER, W.; VEEN VAN, J.A.R. On the role of Ru and $\mathrm{Sn}$ as promoters of methanol electrooxidation over $\mathrm{Pt}$. Surface Science, v.335, p.353-360, 1995.

[18] TOSHIMA, N., YONEZAWA, T. Bimetallic nanoparticles - novel materials for chemical and physical applications. New Journal of Chemistry. New Journal of Chemistry, p. 1179-1201, 1998.

[19] RAQ, C. N., THOMAS, P. J., KULKAMI, G.U. Nanocrystals: Synthesis, Properties and Applications. Springer Series in Materials Science, p. 34, cap. 2, 1995.

[20] WANG, X., HSING, I-M. Surfactant stabilized $\mathrm{Pt}$ and $\mathrm{Pt}$ alloy electrocatalyst for polymer electrolyte fuel cells. Electrochimica Acta, v. 47, p. 2081, 2002.

[21] CHEN, W. X., LEE, J. Y., LUI, Z. Microwave- assisted systhemes of carbon supported $\mathrm{Pt}$ nanoparticles for cell applications. Chemical Communications, p. 2588, 2002.

[22] SPINACÉ, E. V;; OLIVEIRA NETO, A.; VASCONCELLOS, T. R. R.; LINARDI, $M$. Electro-oxidation of ethanol using PtRu/C electrocatalysts prepared by alcohol-reduction process Journal of Power Sources, v. 137, p. 17, 2004.

[23] SPINACÉ, E.V.; NETO, A.O.; VASCONCELOS, T. R. R.; LINARDI, M. Pedido de Depósito de Patente INPI-R.J, PI0304121-2, 2003.

[24] OLIVEIRA NETO, A., DIAS, R. R.; Tusi, M. M.; LINARDI, M.; SPINACE, E. V. Electro-oxidation of methanol and ethanol using PtRu/C, PtSn/C and PtSnRu/C elecirocatalysts prepared by an alcohol-reduction process. Journal of Power Sources, v. 166, p. 87 91, 2007.

[25] OLIVEIRA NETO, A., SPINACE, E. V.; DIAS, R. R.; RIBEIRO, V. A.; LINARDI, M. Eletro-oxidação de etanol sobre eletrocatalisadores $\mathrm{PtRh} / \mathrm{C}, \mathrm{PtSn} / \mathrm{C}$ e $\mathrm{PtSnRh/C}$ preparados pelo método da redução por álcool. Eclética Quimica, v. 31, n. 1, p. 81-88, Brasil, 2006.

[26] OLIVEIRA NETO, A., VASCONCELOS, T. R. R.; VERJULIO R. W. R.; LINARDI, M., SPINACE, E. V. Electro-oxidation of etthylene glycol on PtRu/C and PtSn/C electrocatalysts prepared by alcohol reduction process. Journal of Applied Electrochemisty, v. 35, n. 2, p. 193198, Estados Unidos, 2005. 
[27] OLIVEIRA NETO, A.; LINARDI, M.; SPINACE. E. V. Electro-oxidation of ethylene glycol on $\mathrm{PtSn} / \mathrm{C}$ and $\mathrm{PtSnNi/C}$ electrocatalysts. lonics, $\mathrm{V}$. 12, p. 309-313, 2006.

[28] SPINACE, E. V., LINARDI, M., OLIVEIRA NETO, A. Co-catalytic effect of nickel in the electro-oxidation of ethanol on binary Pt-Sn eletrocatalysts. Electrochemistry Communications, v. 7, p. 365 , 2005.

[29] ANTOLINI, E. Platinum-based ternary catalysts for low temperature fuel cells Part II. Electrochemical properties. Applied Catalysis B: Environmental, v. 74, p.337-350, 2007.

[30] REDDINGTON, E., SAPIENZA, A., GURAU, B., VISWANATHAN, R., SARANGAPANI, S., SMOTKIN, S. E., MALLOUK, E. T. Combinatorial electrochemistry: A highly parallel, Optical screening method for discorery of better electrocatalysts. Science, v. 280, p. 1735, 1998.

[31] PARK, K-W., CHOI, J-H., KWON, B-K., LEE, S-A., SUNG, Y-E, HA, H-Y., HONG, S-A., KIM, H. K., WIECKOWSKI, A. Chemical and electronic effects of $\mathrm{Ni}$ in $\mathrm{Pt} / \mathrm{Ni}$ and $\mathrm{Pt} / \mathrm{Ru} / \mathrm{Ni}$ alloy nanoparticles in methanol electrooxidation. Journal of Physica، Chemistry B, V. 106, v. 106, p.1869 - 1877, 2002.

[32] WANG, Z.B., YIN, P.G., SUN, C. Y. Novel Pt-Ru-Ni/C catalysts for methanol electro-oxidation in acid medium. Electrochemical and Solid-State Letters, v. 9, p. A13 - A15, 2006.

[33] WANG, Z.B., YIN, G.P., ZHANG, J., SUN, C. Y., SHI, P. F. Cocatalytic effect of $\mathrm{Ni}$ in the methanol electro-oxidation on $\mathrm{Pt}-\mathrm{Ru} / \mathrm{C}$ catalyst for direct methanol fuel cell. Electrochimica Acta, v. 51 , p.5691, 2006.

[34] MARTINEZ-HUERTA, M. V.; ROJAS, S.; GÓMEZ DE LA FUENTE, J. L.; TERREROS, P.; PENA, M. A.; FIERRO, J.L.G. Effect of $\mathrm{Ni}$ addition over PtRu/C based electrocatalysts for fuel cell applications. Applied Catalysis B: Environmental, v. 69, p. 75, 2006.

[35] ZHANG, X.; ZHANG, F.; GUAN, R-F.; CHAN, K-Y. Preparation of PtRu-Ni ternary nanoparticles by microemulsion and eletrocatalytic for methanol oxidation Materials Research Bulletin, p. 42, v. 327, 2007.

[36] JEON, K. M., LEE, R. K., DAIMON, H., NAKAHARA, A., WOO, I. S. Pt45Ru45M10/C ( $\mathrm{M}=\mathrm{Fe}, \mathrm{Co}$, and $\mathrm{Ni}$ ) catalysts for methanol electrooxidation. Catalysis Today. v. 132, p. 123-126, 2008.

[37] LIU, J., CAO, J., HUANG, Q., LI, X., ZOU, Z., YANG, HUI. Methanol oxidation on carbon-supported Pt-Ru-Ni ternary nanoparticle electrocatalysts. Journal of Power Sources. v. 175, p. 159-165, 2008.

[38] VOGEL, I. A., BASSETT, J., DENNY, DENNEY, M. Análise química quantitativa. Ed. Guanabara Koogan, p. 151, $5^{\mathrm{a}}$ ed. 
[39] RADMILOVIC, V.; GASTEIGER, H. A.; ROSS, P. N. JR. Structure and chemical composition of a supported Pt-Ru Electrocatalyst for Methanol Oxidation. Journal of Catalysis, v. 154, p. 98, 1995.

[40] BATURINA, O. A.; AUBUCHON, S. R.; WYNNE, K. J. Thermal stability in air of Pt/C catalysts and PEM fuel cell catalyst layers. Chemistry of Materials, v. 18, p. 1498, 2006.

[41] NETO, A.O.; GIZ, M. J.; PEREZ, J.; TICIANELLI, E. A.; GONZALEZ, $E$. R. The electro-oxidation of ethanol on Pt-Ru and Pt-Mo particles supported on high-surface-area carbon. Journal of the Electrochemical Society, v. 149, p. A272, 2002.

[42] OLIVEIRA NETO, A.; FRANCO, E.; SPINACE, E. V.; LINARDI, M.; GONZALEZ, E. R. Métodos de preparação de eletrocatalisadores (nanoparticulas metálicas dispersas em carbono de alta área superficial) para aplicação como ånodo em células a combustivel com membrana trocadora de prótons (PEMFC). Quimica Nova, v. $27, \mathrm{n}$. 4, p. 648-654, Brasil, 2004.

[43] CAMARA, G, A.; LIMA R, B. DE, IWASITA, T. Catalysis of ethanol electrooxidation by PtRu: the influence of catalyst composition. Electrochemistry Communications v 6, p.812, 2004.

[44] WANG, Y., ZHANG, J., WANG, X., REN, J., ZUO, B., TANG, Y. Metal nanoclusters stabilized whith simple ions and solvents-promissing building blocks for future catalysts. Topics in Catalysts, v. 35, p. 3541, 2005.

[45] ROY, A.; SRINIVAS, V.; RAM, S.; DE TORO, J. A.; MIZUTANI, U. Structure and magnetic properties of oxygen-stabilized tetragonal $\mathrm{Ni}$ nanoparticles prepared by borohydride reduction method. Physical Review B, v 71, p. 184443, 2005.

[46] HEGDE, M.S.; LARCHER, D.; DUPONT, L.; BEAUDOIN, B.; TEKAIAELHSISSEN, K.; TARASCON, J.-M. Synthesis and chemical reactivity of polyol prepared monodisperse nickel powders. Solid State Ionics, v. 93, p. 33, 1997.

[47] HYUNG-SUK OH, JONG-GIL OH, YOUN-GI HONG, HANSUNG KIM. Investigation of carbon-supported $\mathrm{Pt}$ nanocatalyst preparation by the polyol process for fuel cell applications. Electrochimica Acta, v 52, p. $7278,2007$.

[48] REN, LI., XING, Y. Effect of pH on PtRu eletrocatalysts prepared via a polyol process on carbon nanotubes. Electrochimica Acta, v. 53, p. 5563, 2008. 